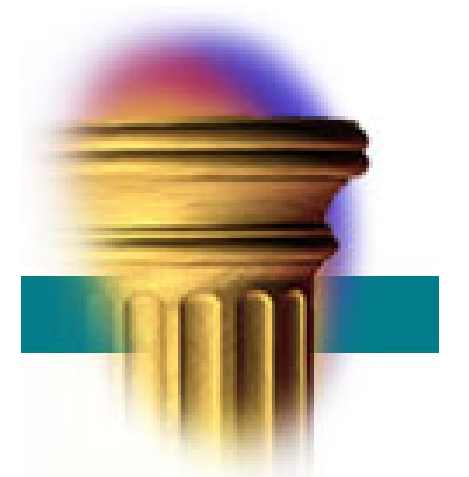

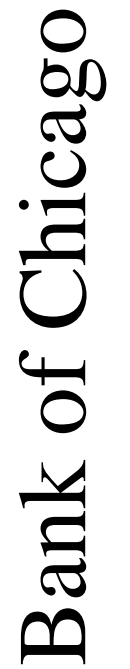

Momentum Trading, Return Chasing, and Predictable Crashes

Benjamin Chabot, Eric Ghysels, and

Ravi Jagannathan

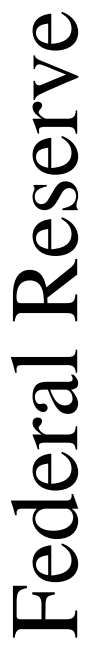

November 2014

WP 2014-27 


\title{
Momentum Trading, Return Chasing, and Predictable Crashes
}

\author{
Benjamin Chabot* \\ Eric Ghysels \\ Ravi Jagannathan
}

\begin{abstract}
:
We combine self-collected historical data from 1867 to 1907 with CRSP data from 1926 to 2012, to examine the risk and return over the past 140 years of one of the most popular mechanical trading strategies - momentum. We find that momentum has earned abnormally high riskadjusted returns - a three factor alpha of 1 percent per month between 1927 and 2012 and 0.5 percent per month between 1867 and 1907 — both statistically significantly different from zero. However, the momentum strategy also exposed investors to large losses (crashes) during both periods. Momentum crashes were predictable - more likely when momentum recently performed well (both eras), interest rates were relatively low (1867-1907), or momentum had recently outperformed the stock market (CRSP era) - times when borrowing or attracting return chasing "blind capital" would have been easier. Based on a stylized model and simulated outcomes from a richer model, we argue that a money manager has an incentive to remain invested in momentum even when the crash risk is known to be high when (1) he competes for funds from return-chasing investors and (2) he is compensated via fees that are convex in the amount of money managed and the return on that money.
\end{abstract}

JEL No. G1,G12,G14

Benjamin Chabot Federal Reserve Bank of Chicago ben.chabot@chi.frb.org
Ravi Jagannathan

Kellogg School of Management and NBER rjaganna@northwestern.edu

Eric Ghysels

Department of Economics and Department of Finance

Kenan-Flagler Business School

University of North Carolina-Chapel Hill

and CEPR

eghysels@unc.edu

\footnotetext{
* The views expressed in this article are those of the author and do not necessarily reflect those of the Federal Reserve Bank of Chicago or Federal Reserve System.
} 
An increasing amount of capital is devoted to trading strategies that mechanically construct portfolios to exploit market anomalies such as "value" or "momentum". The latter strategy — buying recent winners and selling recent losers - is one of the oldest stock-selection strategies still in practice, presumably because of its continued profitability over the years. ${ }^{1}$ One might have expected the profitability of the momentum strategy (momentum premium) to disappear after it became well known in the early 1990s and attracted the attention and capital of professional money managers. Indeed, the momentum premium seemed to have vanished around the early 2000s, and yet reappeared in recent years. Such a simple yet resilient money making strategy requires a new look.

By “new look" we mean (1) using an entirely new long historical data set and (2) using a new model. We combine self-collected historical data with existing data to document the returns to momentum investing in the CRSP-era United States and Victorian-era London. A consistently applied momentum strategy generated abnormal returns across both periods. While the momentum strategy has high historical average abnormal risk adjusted return (alpha), the strategy is prone to periodic crashes. Thus, while investors could enjoy high abnormal average returns by buying winners and selling losers, the momentum strategy exposed investors to large losses with some regularity. It is tempting to argue that investors' aversion to such large losses may not be adequately captured by standard asset pricing models and the high historical alpha is due to inadequate risk adjustment, and is compensation for exposure to such crash risk. However, the hazards of these crashes vary in a predictable way across both eras. ${ }^{2}$ show that times when momentum crashes are more likely is predictable during the CRSP era. We find that

\footnotetext{
${ }^{1}$ To be more precise, at least since the time of David Ricardo, who advised, "cut short your losses, let your profits run," the strategy of holding winners and selling losers has been a favorite of stock market advisors. Ricardo's investment maxims - with which he made a fortune speculating on the London Stock Exchange - are quoted in James Grant's 1838 book The Great Metropolis, Vol II (p.58). Nineteenth and early twentieth century investment manuals, such as The Ticker and Investment Digest and The Banker's Magazine, often carried advice columns recommending momentum strategies and stock guides, such as Walter Bagehot's Investors Monthly Manual, Henry Poor's Poor's Manual of Investments, Moody's Manuals, and The Commercial and Financial Chronicle, all of which included statistical information on stock highs and lows over various horizons for readers who wished to use recent momentum to select stocks.

${ }^{2}$ Earlier work by the authors, Chabot et al. (2009), showed that the Victorian era and CRSP era momentum properties were very similar. This earlier work noted cycles in momentum profits but did not link returns to momentum "crashes" or provide a model explaining crash intensities and estimates of an associated empirical hazard model.
} 
states when crashes are more likely had a common feature across the Victorian and CRSP era. ${ }^{3}$ We argue that crashes play an important role in sustaining momentum through limits to arbitrage examined in Schleifer and Vishney (1997).

How can we rationalize such a persistent historical pattern across eras with arguably very different equity trading environments? There were neither hedge funds during the Victorian era, nor electronic trading, for example. What made momentum return patterns so similar? What explains the persistence of momentum profits? Why does a strategy as simple as buy winners and sell losers not become crowded with followers who bid away any abnormally high risk adjusted returns? The fact that momentum strategies show so many similarities across two different eras suggests that the underlying drivers have remained the same. That would be the case if the high average abnormal returns were due to behavioral biases embedded into the way most investors make decisions consistent with the stand taken in the behavioral finance literature. But then, there are sophisticated professional investors who are not subject to such biases, and they should be able drive away any persistent abnormal returns.

We argue that the persistent historical pattern across both eras is because sophisticated investors who had the necessary skills to execute momentum strategies efficiently did not have sufficient capital of their own, and had to rely on other people's money. Indeed, the momentum strategy does require significant trading and therefore requires skill in executing trades at minimal cost. This separation of brains from capital can be overcome by professional managers endowed with trading skills offering their services to investors with capital in exchange for a percentage of the profits (in the latter part of the CRSP sample) or through leverage financed by risky borrowings at suitable interest rates. By itself this does not explain why momentum profits did not get eliminated. For a complete understanding we must look to an additional feature of momentum returns - large crashes predictable occur at times when momentum is attractive to return chasing capital.

If crash risk is hard wired into momentum returns, we should expect periodic rare crashes in both the CRSP and Victorian era in the data to occur at similar times. This is what we find,

\footnotetext{
${ }^{3}$ Daniel and Moskowitz (2014) document momentum crashes in several markets including commodities. Daniel, Jagannathan and Kim (2012) find that call option on the market type features get embedded into momentum strategy returns due to the way the momentum portfolios are formed, exposing momentum to potentially large but rare losses (crashes).
} 
there are periodic rare crashes in both periods and these momentum crashes can be predicted by the same variables across both time periods. Crashes are more likely to occur during times when managers who use other people's money would find it easier to attract blind capital. These are also times when managers will not commit their own capital to momentum strategy but will still commit other people's money - and those other people will still invest in momentum through managers, knowing that this is the way managers behave. When crashes occur, return-chasing blind capital is exposed to large losses, and that keeps blind capital away for a while. That may explain momentum cycles, where we see momentum disappearing periodically, only to reappear later. The periodic crashes are what keep momentum alive, supporting the "limits to arbitrage" explanation of persistent anomalies of Shleifer and Visney (1997).

A number of papers have suggested a link between investor behavior and crash risk. For example, DeLong et al. (1990) highlight that even without any incentive problems, rational traders may front run positive feedback traders in the market, exacerbating later crashes. Hong and Stein (1999) provide another model where the interactions between two groups of traders can lead to price momentum and reversals. In the presence of incentive problems, Vayanos and Woolley (2013) explicitly model momentum driven by professional managers.

To the best of our knowledge, however, the existing models do not feature the periodically reoccurring moment cycles with the predictable time varying crash likelihood we observe in the long historical sample. While we are not the first to notice cyclicality in momentum returns, one of our contributions is to introduce a hazard model that successfully captures the time-varying likelihood of momentum downturns.

Exploiting momentum involves the use of other people's money either as a skilled investor relying on leverage or as a professional financial intermediary who manages other people's money. If capital constraints prevent skilled investors from driving abnormal momentum returns to zero, we hypothesize that a measure of capital scarcity should predict the duration of momentum profit cycles. To test this formally, we introduce a new methodology based on modeling profit duration dynamics as a function of the risk-free rate, the past stock market return, and the past performance of the momentum strategy, which we interpret as a proxy for the scarcity of capital available to skilled momentum traders. Consistent with models of leverage-induced crashes, we find strong statistical evidence that our proxy for capital available to momentum traders predicts sharp downturns in momentum profits. 
After documenting the predictability of momentum crashes, we introduce a theoretical model to illustrate why rational managers will commit other people's money to momentum when crashes are more likely - even when they will not commit their own capital. In fact, times when large losses are likely are times when momentum has done better than the market and managers will find it easy to attract the capital of return chasing investors, i.e., blind capital. That exposes blind capital to crash losses. One consequence is also that other people's money available to sophisticated investors will be scarce following such crash losses, thereby letting momentum alive.

For analytical tractability, the theoretical model is limited to three time periods, two money managers and two market states. While this simplicity illuminates the money managers decisions, the model lacks the rich dynamics of modern delegated finance. We therefore use simulations to verify that the theoretical model explanation remain valid in richer economies with many money managers, states of nature, and time periods. In addition, the investors in our model perfectly understand the behavior of managers, and still choose to let them manage their money. The simulated model — calibrated to mimic the aforementioned duration properties of momentum cycles - explains the apparent paradox that even though large momentum losses are predictable, sophisticated money managers may nonetheless choose to crowd into this strategy at times of elevated risk. Our money managers are compensated by collecting fees equal to a small percentage of assets under management and a larger percentage of profits above a high-water mark. These managers compete with each other for the blind capital of return-chasing customers. In our simulations calibrated with CRSP data, money managers who go to cash in periods of elevated crash risk are less profitable on average than managers who remain invested in the momentum strategy. While we do not model the behavior of momentum investors of the Victorian era who relied on borrowed funds to invest in momentum strategies, we conjecture that in light of the risk-shifting payoffs of margin loans, they too would have had little incentive to exit when crash probabilities became high.

The paper is organized as follows. In Section 1 we introduce and describe the new data and document the similarities between momentum profits in the Victorian and CRSP eras. Our main results - that momentum profits exhibit predictable cycles: they stochastically vanish and reemerge - are presented in Section 2. We characterize this stochastic periodicity using a hazard model that successfully predicts transitions into momentum strategy bear markets as a function 
of the recent relative attractiveness of the momentum strategy. In Section 3 we provide a possible explanation for this phenomenon based on simulations of a stylized partial-equilibrium model economy calibrated to the data. Section 4 concludes. Details about the unique data set can be found in the Appendix.

\section{Stock Price Momentum during CRSP and Victorian Eras: Abnormal Returns and Cyclical Profits}

There is a very large literature on momentum which we cannot possibly summarize. Most relevant for our work are papers addressing momentum and limit to arbitrage issue. In particular, when an anomaly exists but only a limited number of investors have both the capital and skill to devote to a trading strategy designed to exploit it, they may not have enough collective resources to drive the anomalous returns to zero. Typically, skilled investors will seek to expand their profitable positions either through trading leverage (short positions funding long positions) or by soliciting outside capital from less skilled investors. However, in theoretical models such as Aiyagari and Gertler (1999), Gromb and Vayanos (2002), Geanakopolis (2003), Fostel and Geanakopolis (2008), Brunnermeier and Pedersen (2009) and Kondor (2009) leverage constraints can result in sudden reversals if idiosyncratic declines lower the value of collateral and force correlated liquidations. Fear of forced liquidations limit the leverage arbitrageurs are willing to employ and therefore the capital these arbitrageurs can devote to eliminating anomalies. Moreover, when arbitrageurs raise equity from uninformed outside investors, poor returns can result in contagious liquidations if outside investors interpret losses as evidence that they have a low quality investment manager. In models such as Shleifer and Visney (1997), Liu and Longstaff (2004), and Acharya et al. (2010) idiosyncratic volatility combines with the fear of outside investor flight to prevent arbitrageurs from devoting sufficient capital to high alpha investments.

Khandani and Lo (2007) and Mitchell et. al. (2007) document recent examples of shocks that interact with leverage and capital constraints to generate forced liquidations and sudden reversals in otherwise high return low systematic-risk strategies such as long-short quant funds and convertible arbitrage funds. Ambastha and Ben Dor (2010) observed the same pattern for the Long Barclays Alternatives Repliators, a particular hedge funds index clone. Hedge fund clones 
rely on price momentum to some extent and Ben Dor, Jagannathan, Meier, and Xu (2011) find that an index of six hedge fund clones exhibits the same pattern. Financial crises are times when banks and other intermediaries withdraw funding that is otherwise available to arbitrageurs and Daniel and Moskowitz (2014) document a similar breakdown in performance in momentum strategies during the financial crisis. Elavia and Kim (2011) provide an explanation for a closely related phenomenon based on how investors perceive risk and make decisions and Daniel, Jagannathan and Kim (2012) make use of this pattern to identify hidden turbulent market conditions when momentum crashes become more likely. More on point, Daniel and Moskowitz (2014) document that infrequent crashes skew returns from momentum strategies across numerous asset classes. These momentum crashes are the necessary ingredient to limit arbitrage with other people's money.

We revisit these issues with a new hand-collected data set of the London Stock Exchange. ${ }^{4}$ Our data set consists of the closing prices, dividends, and shares outstanding of 1,808 stocks listed in London between 1866 and 1907. These data include virtually every stock traded on the London Stock Exchange during this period. In some ways the Victorian capital markets are an ideal laboratory to study momentum theories. The pre-WWI London Stock Exchange had no capital gains tax distortions, and it was remarkably easy to retail investors to short shares and form leveraged long-short portfolios. ${ }^{5}$

We consider two measures of returns from momentum strategies. The first is the return an investor would receive from holding the Fama-French momentum factor portfolio. ${ }^{6}$ The

\footnotetext{
${ }^{4}$ Pre-CRSP-era historical data have been used before to assess some of the salient empirical features of asset returns. Schwert (1989) uses 1857-1986 U.S. stock return data to investigate the cause of stock volatility. Schwert (1990) analyzes the relation between stock returns and real economic activity with 1889-1988 U.S. stock data. Goetzmann (1993), Goetzmann, Ibbotson, and Peng (2001) and Annaert and Van Hyfte (2006) study long-term predictability in London since 1695 , the NYSE between 1815 to 1925 , and the $19^{\text {th }}$ century Brussels stock exchange, respectively.

${ }^{5}$ The LSE used fortnightly clearing that minimized the costs of forming long-short portfolios. On the day before settlement, the LSE clearing house ran a netting operation where shorts who did not want to deliver shares could be matched with longs who did not wish to take delivery. Supply and demand was equated by the "contango" or "backwardation" rate - the repo rate paid by longs and shorts to carry their position for another 14 days. Thus, shorting involved none of the search frictions modeled in papers such as Duffie et al. (2002). See Rates of Interest on Collateral Call Loans $66^{\text {th }} 2^{\text {nd }}$ session Congress Senate Doc 262 for a description of shorting on the Victorian LSE and a comparison to practice on the NYSE.

${ }^{6}$ The momentum factor portfolio is formed monthly by sorting stocks at time t into one of six value-weighted portfolios formed on size and month t-12 to t-1 return. The six portfolios are the intersections of two portfolios formed on size and three portfolios formed on prior return. The monthly size breakpoint is the median NYSE market
} 
second, which we call the FF7030 portfolio, is computed from the Fama-French decile portfolios formed monthly on momentum. The FF7030 portfolio is the return an investor would receive from buying a value-weighted combination of the three Fama-French decile momentum portfolios with prior returns above the $70^{\text {th }}$ percentile and shorting a value-weighted combination of the three portfolios with prior returns below the $30^{\text {th }}$ percentile. $^{7}$

Table 1 reports the average, standard deviation and skew of momentum portfolio returns in the United States between 1927 and 2012 and London between 1867 and 1907. Momentum strategies generated positive returns with remarkably similar Sharp ratios across both eras, but the CRSP-era NYSE momentum portfolios generated higher average returns along with more variance and skewness.

CRSP-era momentum is a well-known anomaly. The CRSP-era Fama-French momentum factor and 7030 portfolio returns cannot be explained by their exposure to the Fama-French market, small minus big (SMB), and the high book-to-market minus low book-to-market (HML) risk factors. Were momentum returns always abnormal? Table 1 also reports the coefficients from a regression of momentum portfolio returns on two three-factor models:

$$
\begin{aligned}
& R_{m o m, t}=\alpha+\beta_{(m k t)}\left\{R_{m k t}-R_{f}\right\}_{t}+\beta_{(S M B)}\left\{R_{S M B}\right\}_{t}+\beta_{(H M L)}\left\{R_{H M L}\right\}_{t}+\varepsilon_{t} \\
& R_{\text {mom }, t}=\alpha+\beta_{(m k t)}\left\{R_{m k t}-R_{f}\right\}_{t}+\beta_{(\text {Size })}\left\{R_{\text {size }}\right\}_{t}+\beta_{(\text {divyield })}\left\{R_{\text {divyield }}\right\}_{t}+\varepsilon_{t}
\end{aligned}
$$

The first model (1) is the familiar Fama-French three-factor model, where the SMB size factor and the HML value factor are both formed from double sorts that require accounting-book value. Unfortunately, accounting data are either unavailable or unreliable for most stocks trading in London before 1907. We therefore estimate a second three-factor model (2) with size and value factors formed on variables observable in the pre-1907 London market. Our size factor (Size) is a monthly small-minus-big portfolio formed by buying a value-weighted portfolio of all stocks with a market value below the median and shorting a value-weighted portfolio of all stocks with

equity. The prior return breakpoints are the 30th and 70th percentiles. The momentum factor portfolio is the average return on the two high prior return portfolios minus the average return on the two low prior return portfolios,

${ }^{7}$ Fama-French portfolios are derived based on data from CRSP US Stock Database @2013 Center for Research in Security Prices (CRSP), The University of Chicago Booth School of Business.” Available online at http://mba.tuck.dartmouth.edu/pages/faculty/ken.french/data_library.html. 
a market value above the median. Our value factor (Divyield) is a monthly high-minus-low portfolio formed on dividend yield. We form this value factor by sorting stocks each June based on the same criteria that Fama and French use to construct portfolios formed on dividend yield. Fama and French assign stocks to one of four portfolios based on dividend yield (no dividend, bottom $30 \%$, middle $40 \%$, top 30\%). Our high-minus-low dividend yield portfolio is the monthly return on the top $30 \%$ of dividend-yielding stocks minus the return on the stocks that paid no dividends.

Table 1 reports the regression coefficient from monthly time-series regressions of momentum strategy returns on the factors in (1) and (2) for the CRSP-era United States and (2) for the pre-1907 London stocks. The monthly CRSP-era momentum factor alpha is 101 basis points in both specifications (1) and (2), and the monthly CRSP-era FF7030 alpha is 88 and 89 basis points, respectively. The similarity of alphas across specifications (1) and (2) reassure us that our alternative size and value factors capture the risks spanned by the traditional FamaFrench SMB and HML factors.

The momentum strategy generated positive alpha in pre-1907 London as well. An investor who held the Fama-French momentum factor or the FF7030 portfolio would have enjoyed 28-day alphas of 52 and 49 basis points, respectively. The pre-1907 alphas are only 55\% as large as the CRSP-era alphas, but the momentum strategy generated strongly statistically significant abnormal returns.

While the momentum strategy generated comparable Sharp ratios and statistically significant alphas across both sample periods, the Victorian-era momentum returns were less negatively skewed. Presumably, the limited role of delegated portfolio management during the Victorian era diminished the crash risk due to contagious investor liquidations. However, the ease with which Victorian retail investors could finance long-short positions in the stock lending market suggests the risk of crashes due to binding leverage constraints discussed earlier remained.

\subsection{Dating Momentum Bull and Bear Markets}

The momentum returns across both eras can be characterized by abnormally high returns punctuated by occasional steep but predictable losses. To show this, we first date momentum bull 
and bear markets via the Lunde and Timmermann (2004) algorithm. Bull (Bear) markets are colloquially defined as a long-term upward (downward) trend in prices with inconsequential interruptions. Lunde and Timmermann (2004) formalize this intuition with a dating algorithm, which we briefly describe next. ${ }^{8}$

Assume time is measured at discrete intervals and the price of the portfolio of interest at the end of time $t$ is $\mathrm{P}_{\mathrm{t}}$. Let $\mathrm{I}_{\mathrm{t}}$ be a bull market indicator equal to 1 if we are in the bull state at time $t$ and 0 otherwise. Let $\lambda_{1}$ be a scalar defining the threshold of stock price movements that trigger a switch from a bear to a bull market and $\lambda_{2}$ the threshold of stock price movements that trigger a switch from a bull to a bear market. Suppose that at time $t_{0}$ the portfolio is in a bull market at a local maximum $\left(\mathrm{I}_{\mathrm{t} 0}=1\right)$. Set $P_{t 0}^{\max }=P_{t 0}$, where $P_{t 0}$ is the value of the portfolio at time $t_{0}$. Let $\tau_{\max }$ and $\tau_{\min }$ be stopping-time variables defined by

$$
\begin{aligned}
& \tau_{\max }\left(P_{t 0}^{\max }, t_{0} \mid I_{t_{0}}=1\right)=\inf \left\{t_{0}+\tau: P_{t_{0}+\tau} \geq P_{t 0}^{\max }\right\}, \\
& \tau_{\min }\left(P_{t 0}^{\max }, t_{0}, \lambda_{2} \mid I_{t_{0}}=1\right)=\inf \left\{t_{0}+\tau: P_{t_{0}+\tau}<\left(1-\lambda_{2}\right) P_{t 0}^{\max }\right\} .
\end{aligned}
$$

The $\min \left(\tau_{\max }, \tau_{\min }\right)$ is the first time the price crosses one of two barriers $\left\{P_{t 0}^{\max },(1-\right.$ $\left.\left.\lambda_{2}\right) P_{t 0}^{\max }\right\}$. If $\tau_{\max }<\tau_{\min }$, then we have a new local max. Update the current bull market state by setting $I_{t}$ equal to 1 when $t$ is in the interval $t_{0+1}$ to $t_{0+\tau_{\max }}$ and $P_{t 0+\tau_{\max }}^{\max }=P_{t 0+\tau_{\max }}$ and continue with the new local max.

Conversely, if $\tau_{\min }<\tau_{\max }$, the price has declined by a sufficient amount to switch from a bull to a bear market that has prevailed since $t_{0}$. Set $I_{t}$ equal to 0 when $t$ is in the interval $t_{0+1}$ to $t_{0+\tau_{\min }}$ and define $P_{t 0+\tau_{\min }}^{\min }=P_{t 0+\tau_{\min }}$. If the starting point at $t_{0}$ is a bear market, then the stopping times are defined as

$$
\begin{aligned}
& \tau_{\min }\left(P_{t 0}^{\min }, t_{0} \mid I_{t_{0}}=0\right)=\inf \left\{t_{0}+\tau: P_{t_{0}+\tau} \leq P_{t 0}^{\min }\right\} \\
& \tau_{\text {max }}\left(P_{t 0}^{\min }, t_{0}, \lambda_{1} \mid I_{t_{0}}=0\right)=\inf \left\{t_{0}+\tau: P_{t_{0}+\tau}>\left(1+\lambda_{1}\right) P_{t 0}^{\min }\right\} .
\end{aligned}
$$

\footnotetext{
${ }^{8}$ This description is taken from Lunde and Timmermann (2004, p. 254-255).
} 
This algorithm partitions the momentum return time series into bull or bear markets (i.e., $I_{t}=0$ or $I_{t}=1$ for all $\left.t\right)$. We consider symmetric thresholds $\left(\lambda_{1}=\lambda_{2}\right)$ for transitions between bull and bear markets. There is no consensus on what the thresholds should be. Exceedingly large thresholds will result in few transitions between bull and bear market states and are likely to diminish the power of our hazard model analysis. On the other hand, if we set the thresholds too small, we run the risk of labeling small fluctuations, which may be inconsequential to the decision making of momentum traders. We weigh these trade-offs and decide to choose symmetric 5\% and $10 \%$ transition thresholds. We think these thresholds are large enough to affect the behavior of momentum investors who often employ leverage and are therefore sensitive to even small drawdowns while remaining small enough to generate a number of cycles in the data.

Table 2 reports the frequency, duration, and average cumulative loss from momentum strategy bear markets during both the CRSP and Pre-1907 eras. The CRSP-era momentum factor and the FF7030 portfolios suffered bear market declines of at least 5\% 63 and 68 times, respectively, between 1927 and 2012. Bear markets of at least 5\% occurred approximately every 15-16 months, and the average cumulative loss was $13.6 \%$ and $14.8 \%$, respectively!

Given the absence of the delegated portfolio managers in the Pre-1907 era, we should expect crashes to be less severe and less frequent. In fact, bear markets in momentum were both less frequent and more benign before 1907. While the momentum factor and 7030 portfolios suffered bear market declines of at least $5 \%$ every 16 or 15 months, respectively, during the CRSP era, these same strategies suffered bear markets every 28 or 25 months during the pre1907 era. When bear markets did occur, both the speed and magnitude of declines were smaller. The past 150 years illustrate that there is clearly more to momentum returns than large alphas. Although the momentum strategy generated high abnormal returns on average, the strategy has exposed momentum traders to brief but sharp declines. Cyclicality is consistent with many behavioral and rational explanations of momentum. Cooper, Gutierrez, and Hameed (2004) note that the theory of Daniel, Hirshleifer, and Subrahmanyam (1997) predicts differences in momentum profits across states of the market. Momentum cycles may also reflect changing risk over the business cycle. Chordia and Sivakumar (2002) show that macroeconomic instruments commonly used for measuring macroeconomic conditions can 
explain a large portion of momentum profits. Moskowitz, Ooi, and Pedersen (2012) find that momentum across many markets is consistent with initial under-reaction and the trading behavior of speculators, while Asness, Moskowitz, and Pedersen (2013) find that momentum across many markets can be partially explained by liquidity and long-run consumption risks.

As noted in the Introduction, we are not the first to notice cyclicality in momentum returns or the predictability of momentum crashes. One of our contributions is to introduce a hazard model that successfully captures the time-varying likelihood of momentum downturns, and examine the extent to which market conditions when momentum crashes become more likely are the same during the Victorian and CRSP eras.

\section{Predictable Momentum Cycles}

If capital constraints prevent skilled investors from driving excess momentum returns to zero, we speculate that a measure of capital scarcity should predict the duration of momentum profit cycles. To test this formally, we introduce a new methodology based on modeling profit duration dynamics as a function of the risk-free rate, the past stock market return, and the past performance of the momentum strategy, which we interpret as a proxy for the scarcity of capital available to skilled managers employing momentum strategies.

Fund managers find it easier to attract new assets when their past performance is strong. ${ }^{9}$ Likewise, self-leveraged investors have more money to invest when their strategy has performed well in the recent past. The past return of the momentum strategy is therefore likely to contain information about how crowded the momentum trade is. Money crowding into the momentum strategy is likely to both reduce any future returns attributable to slow moving capital and increase the probability that a negative shock will result in a large decline as more leveraged investors are forced to liquidate and rush for the exit.

If capital constraints do limit arbitrage, we would expect a measure of capital scarcity to predict the duration of momentum profit cycles. We model the hazard of the momentum strategy transitioning from a bull to a bear market and find strong evidence that

\footnotetext{
${ }^{9}$ Agarwal, Daniel, and Naik (2009) and Fung, Hsieh, Naik, and Ramadorai (2008) have documented the AUM Flow-Performance Relationship with individual hedge funds and funds of funds, respectively.
} 
our proxy for capital available to momentum traders predicts momentum cycles.

\subsection{The Discrete Time Hazard Model}

We model the hazard of a transition from a momentum strategy bull market to a bear market. We start with the assumption that the data are generated with a continuous time process with a proportional hazard

$$
h(t, \boldsymbol{X})=h_{0}(t) e^{\beta^{\prime} \boldsymbol{X}} .
$$

$h_{0}(t)=\gamma \rho t^{\rho-1}$ is the baseline Weibull hazard, where $t$ is the age of the bull market and $\mathbf{X}$ are covariates that shift the hazard relative to the baseline. The Weibull specification allows for duration dependence in the baseline hazard. If $\rho>1$, the baseline hazard increases as the bull market ages; if $\rho<1$, the baseline hazard decreased as the bull ages; and if $\rho=1$, the baseline hazard becomes the exponential model with constant hazard.

When the data are generated by (5), Prentice and Gloeckler (1978) derive the discrete time hazard with time-varying covariates. The probability that a bull market ends at time $t$ is $P r_{t}$ :

$$
P r_{t}=1-e^{-h_{t} e^{\beta^{\prime} x_{t}}}
$$

where $h_{t}=e^{\alpha+(\rho-1) \ln (t)}$ is the Weibull baseline hazard.

Let $d_{t}$ be a dummy variable equal to 1 if the bull market ends at time $\mathrm{t}$ and 0 otherwise. The discrete time log-likelihood function is ${ }^{10}$

$$
\text { Ln } L=\sum_{t=1}^{T_{\text {bull }}} d_{t} \ln \left(\frac{P r_{t}}{1-P r_{t}}\right)+\sum_{t=1}^{T_{b u l l}} \ln \left(1-P r_{t}\right),
$$

where $T_{\text {bull }}$ is the number of time periods at risk (the number of time periods in bull markets).

We estimate (7) via maximum likelihood with three covariates in $\mathbf{X}_{\mathbf{t}}$. Our first

${ }^{10}$ See Allison (1982) 
covariate - the level of the time $t$ risk-free rate-captures the opportunity cost of capital. Our second and third covariates are the cumulative return on the momentum portfolio and the value-weighted market portfolio from time $(t-12)$ to $(t-1)$-which captures the performance of the momentum strategy relative to the market over the past year.

\subsection{Empirical Findings}

The estimated hazard model coefficients are reported in Table 3. Holding the past return on the market fixed, high past returns on the momentum strategy increase the odds of the onset of a bear market in momentum in both the NYSE CRSP and Pre-1907 London data. On the other hand, holding the past momentum return fixed, higher past returns on the market lower the odds of entering a bear market in momentum during the CRSP era, but increase the odds of entering a bear market in the Victorian era, and statistically significantly so for the 7030 momentum strategy. Again, this is consistent with the institutional differences across the two eras. In the Victorian era, when delegated portfolio management was not in vogue, individual investors engaging in momentum trading financed their positions by pledging their financial assets as collateral. An increase in the level of the stock market would increase collateral values, thereby reducing the odds of crashes induced by forced selling to meet collateral calls. In contrast, during the CRSP era, when professional money management became more prevalent, superior past stock market performance would decrease the relative attractiveness of investing in momentum strategies to owners of money, especially return-chasing blind capital. Consequently, momentum strategies were likely to be less crowded following superior stock market performance. ${ }^{11}$

High levels of the risk-free rate decreased the odds of a bear market in momentum during the Victorian era but had no effect on bear market odds in the CRSP sample. Again, this is consistent with institutional differences. In the Victorian era, absent the availability of other peoples' money, a momentum trader could only deploy large amounts of money

\footnotetext{
${ }^{11}$ See Agarwal et al. (2009) and Fung et al. (2008) for the effect of relative performance on investment flows.
} 
through margin borrowing. ${ }^{12}$ An increase in the level of the risk-free rate raised the cost of margin borrowing, which would make the momentum strategy funded by margin borrowing less attractive and consequently less crowded.

The hazard models do an excellent job fitting the data. Momentum bear markets can be forecasted with surprising precision. Figure 1 plots the receiver-operating-characteristic (ROC) curve for the full model estimated with the CRSP-era data and the Fama-French momentum factor. ${ }^{13}$ In our context, the hazard model generates a time-varying probability of transitioning to a bear market. A money manager who wishes to avoid bear markets could select a discrimination threshold above which he will exit momentum and move into cash.

Partition the data sample into crash months (denoted by $C$ ) and no crash months (denoted by NC). If a crash occurs while the money manager is in cash, the model has correctly predicted that bear. Let $c^{*}$ denote the number of crash months that occur when the manager is in cash. Define the true positive rate as $\frac{c^{*}}{C}$. Similarly, let $n c^{*}$ denote the number of months when the manager is in cash and no crash occurs. Then the false positive rate is $\frac{n c^{*}}{N C}$.

Consider an extremely careful manager who chooses a very low discrimination threshold such that he is always in cash. All crashes will occur when this manager is in cash, and consequently the true positive rate $\frac{c^{*}}{C}$ equals 1 . However, by choosing such a low threshold, the manager will also be in cash every time a crash does not occur, and the false positive rate $\frac{n c^{*}}{N C}$ will also be 1 . As the manager increases the discrimination threshold, both the false positive and true positive rates will decline. The ROC curve plots the trade-off between the true positive and false positive rates as the money manager varies the discrimination threshold above which he will exit the momentum strategy.

The area under the ROC curve (AUC) is a summary statistic of the model's goodness of fit. A model that can successfully predict every transition from bull to bear with no false

\footnotetext{
${ }^{12}$ It was exceptionally easy for a Victorian-era retail investor to lever long-short portfolios with margin loans. See Chapter 17 in Duguid (1902) and Chiswell (1902, p. 11-18) for descriptions of the rules and practice of short selling with margin on the London Stock Exchange.

${ }^{13}$ The ROC curve is a common tool used in engineering, medicine, and machine learning for measuring the accuracy of diagnostic models of rare events. See Swets (1988).
} 
positives will have an AUC of 1, while a model with no ability to forecast will have an AUC of $.5 .{ }^{14}$ Our hazard model is estimated to fit within sample, so even if the underlying data are generated from i.i.d. returns selected at random with no predictability, the estimated AUC will be greater than .5. To evaluate the predictability in a time series of data and a given model, one can bootstrap the AUC by generating data series via random draws with no memory and fit the model to each draw to compute the distribution of AUCs under the null of no predictability. Using this bootstrap procedure, we find that momentum return bear markets are predictably different from random at the $1 \%$ significance level in all specifications.

In addition to the probability of transitioning to a bear market increasing with past momentum returns, the return to investing in momentum conditional on remaining in a bull market also increases with past momentum return.

In Table 4 we select only the realized momentum strategy returns where the momentum portfolio was purchased in a bull market (return realized at time $t$ if $t$ - 1 is a bull state). We partition this data into decile bins based on the percentile rank of momentum strategy returns from time $(\mathrm{t}-12)$ to $(\mathrm{t}-1)$. Therefore, the $1^{\text {st }}$ decile is the one-month return one would receive if they invested in the momentum strategy when the average return of momentum over the past year was in the lowest $10 \%$ of all bull market states, and the $10^{\text {th }}$ decile is the one-month return one would receive if they invested in the momentum strategy when the average return of momentum over the past year was in the highest $10 \%$ of all bull market states.

Conditional on past momentum return deciles, Table 4 reports the probability of transitioning to a bear market, the annualized sharp ratio of the one-month return, and the one-month momentum strategy return conditional on remaining in a bull market or transitioning to a bear market. In the CRSP era, the probability of transitioning to a bear market increases dramatically and the sharp ratio for remaining invested in the momentum strategy declines when the past year's momentum strategy return enters the top decile.

\footnotetext{
${ }^{14}$ For example, the ROC for the naïve model that each month assigns the same probability of transitioning from bull to bear will have two points, $(0,0)$ and $(1,1)$ and the area under the line connecting these points will be .5 .
} 


\subsection{Profiting from Predictability: Managed Portfolios}

As we noted earlier, it is well recognized in the literature that times when momentum crashes are more likely is predictable in real time ${ }^{15}$. What is interesting is that the hazard model coefficients tell us that the probability of a momentum crash increases with the performance of momentum over the past year (relative to the overall stock market) - during the Victorian as well as the CRSP eras. In what follows we illustrate a simple rule that exploits this predictability to manage the investment in the momentum strategy to improve the Sharpe Ratio of the managed portfolio which confirms that momentum risk goes up more than momentum return when momentum has done well in the past.

Define the recent relative performance of momentum at month $t$ as the difference between the return of the momentum strategy and the return on the market index over the past K months: $R_{t}^{m o m-R m}=R_{(t-12) \rightarrow t}^{\text {mom }}-R_{(t-12) \rightarrow t}^{m}$. And define Mpercentile $_{t}^{K}$ as the percentile rank of $R_{t}^{m o m-R m}$ in the set of $\left[R_{t-K+1}^{m o m-R m}, \ldots, R_{t}^{m o m-R m}\right]$.

Consider a portfolio manager who constructs a managed portfolio that switches between the momentum strategy and risk-free security by investing in momentum whenever $R_{t}^{m o m-R m}$ is below a predetermined Mpercentile ${ }_{t}^{K}$ threshold and holds the risk-free asset otherwise. For example, if the manager chooses $\mathrm{K}$ to equal 3 years $(K=36)$ and sets the exit threshold at the $90^{\text {th }}$ percentile, this manager's realized return in month $t+1$ will equal the return on the momentum strategy whenever $R_{t}^{m o m-R m}$ is below the $90^{\text {th }}$ percentile of all $R_{t-35}^{m o m-R m}, \ldots, R_{t}^{m o m-R m}$ and the risk-free return otherwise. We chose $\mathrm{K}=36$ given the well documented long run momentum reversal phenomenon where 36 months was chosen as long run in several empirical studies. When $\mathrm{K}$ is set equal to 36 , the portfolio management rule does not always exit momentum, but only when the threshold is crossed.

Figure 2 plots the change in the CRSP-era Sharp Ratios of managed portfolios formed by switching between the Fama-French momentum factor portfolio and the risk-free asset at different thresholds of Mpercentile ${ }_{t}^{K}$ and $\mathrm{K}=36$ months. A manager who always invests in momentum chooses a threshold of 100 and would have earned a Sharp Ratio of .66 from 1950-2012 and .45 from 1930-2012. A manager who exited momentum and switched to the

\footnotetext{
${ }^{15}$ See Chabot et. al. (2009) Daniel and Moskowitz (2014), Daniel, Kim and Jagannathan (2012) and Baroso and
} Santa Clara (2013). 
risk free asset whenever $R_{t}^{m o m-R m}$ exceeded the $75^{\text {th }}$ percentile of all $R_{t}^{m o m-R m}$ over the past 3 years would have enjoyed a higher Sharp Ratio of .83 between 1950-2012 and .65 between 1930-2012.

\section{Why Money Managers Stay Invested when Crash Risk Is Elevated}

The hazard model coefficients and areas under ROC curves imply that bear markets in momentum can be forecasted based on the past performance of the momentum strategy. The probability of a bear market in momentum increased significantly when the momentum strategy has performed well over the past year. This is consistent with market folk wisdom. The "crowded trade" is common jargon amongst practitioners for a strategy that performed well in the past but has attracted so much money that it is now unprofitable and risky. Nonetheless, some of the empirical evidence suggests that even skilled money managers may crowd into strategies that have generated recent success. ${ }^{16}$

Why would skilled money managers not exit the momentum strategy when the probability of a bear market is high? Two factors diminish the incentives for fund managers to attempt to strategically enter and exit the momentum strategy. First, fund managers are often compensated with incentive fees equal to a portion of profits above a high-water mark and solicit funds from return-chasing investors. The momentum strategy is most likely to transition into a bear market when past returns are high. This is exactly the time when a fund manager is most able to attract more funds and likely to have a high proportion of his assets under management above the high-water mark. The risk-shifting convex payout structure of incentive fees can combine with the return-chasing behavior of future investors to provide incentives for fund managers who have a finite horizon to remain in a crowded momentum strategy. ${ }^{17}$ Secondly, as we discussed earlier, the return to investing in momentum conditional on remaining in a bull market increases with past momentum return as well. Therefore, a manager who exited

\footnotetext{
${ }^{16}$ See Pedersen (2009) for a theoretical overview and example of crowded trades and subsequent crashes. Fung et al. (2008) document the performance-flow relationship in funds of hedge funds and find that capital inflows to funds that have over-performed in the recent past attenuates the ability of past alpha-producing funds to continue to deliver market-beating returns.

${ }^{17}$ Many authors have claimed that the fee structure of hedge funds creates an incentive for excess risks. For instance, see the models of Carpenter (2000) or Goetzmann, Ingersol, and Ross (2003).
} 
momentum when past returns were high would avoid the risk of being invested in momentum during a bear market but would also forgo abnormally high returns should the bull market in momentum persist.

In the remainder of this section, we first illustrate the effects of the convex compensation structure and return-chasing investors on rational fund managers' behavior using a parsimonious two-period game-theoretic model. We then, explore the profitability of various managers' strategies in a richer setting via a simulation that reflects the conditional return dynamics documented Table 4.

\subsection{An Illustrative Model of Fund Managers'Behavior}

Why would a sophisticated money manager remain invested in momentum when the probability of a large decline is high? In this section we present a parsimonious model that illustrates how risk-shifting convex incentive fees and return-chasing investors can combine to provide incentives for fund managers to remain invested in momentum even when the probability of a crash is high.

The model consists of two time periods, two investors, and two fund managers who can allocate funds between cash and the momentum strategy with the following return dynamics.

\section{Returns:}

Each period, the gross momentum return can take one of two values, $R_{\text {up }}>1$ or $R_{\text {down }}<1$. We model the predictability of momentum returns as a two-state Markov process where the states are unobservable to investors but observed by skilled fund managers before making investment decisions. The probability of $\mathrm{R}_{\mathrm{up}}$ is $\mathrm{p}_{\mathrm{UG}}$ in the good state and $\mathrm{p}_{\mathrm{UB}}$ in the bad state with $\mathrm{p}_{\mathrm{UG}}>\mathrm{p}_{\mathrm{UB}}$. The probability of transitioning between states is governed by a $2 \times 2$ Markov transition matrix with the $(i, j)^{\text {th }}$ element $\pi_{\mathrm{i}, \mathrm{j}}$ equal to the probability of transitioning from state $i$ to state $j$.

Investors:

Each of the two investors has $\$ 1$ of saving each period. Investors can allocate this saving between cash with a risk-free unit gross return or deposit it with one or both fund managers who can invest in the risky momentum strategy. In the first period, investors have no signal about the managers' skills and choose to divide all their period 1 savings equally between the two fund managers. In period 2, investors' return-chasing behavior manifests itself in two ways. First, any 
investment in momentum will be allocated to the fund manager(s) who performed best in period 1. Second, investors allocate all of their period 2 savings to the best-performing fund manager(s) if the momentum strategy generated positive returns in period 1 and a smaller amount $(\mathrm{f}<1)$ of their period 2 savings to the fund managers if the momentum strategy generated negative returns in period 1 . We further assume that the flow $f$ is sufficiently small such that $\left(R_{\text {down }}+f\right) * R_{u p}<(1+f)$.

Investor behavior results in the following aggregate cash flows to fund managers based on their period 1 performance. In period 1, \$2 is split equally between the fund managers. If momentum earns a positive return in period 1, an additional $\$ 2$ is allocated to the fund manager with the best period 1 performance or split equally if both managers enjoyed the same return in period 1. If momentum earns a negative return in period 1 , however, $\$ 2 * \mathrm{f}$ is allocated to the fund manager with the best period 1 performance or split equally if both managers enjoyed the same return in period 1.

The fund managers provide investors with access to the momentum strategy via the following contract. Managers take deposits from investors in each period. For analytical convenience, we only allow contracts where any money given to a manager is committed until the end of period 2. At the end of period 2, managers subtract a management fee equal to a proportion $\delta \in[0,1]$ of investment profits and return the remaining money to investors. Due to our assumption that $\left(\mathrm{R}_{\text {down }}+\mathrm{f}\right) * \mathrm{R}_{\mathrm{up}}<(1+\mathrm{f})$, fees will be zero unless the managers' returns are weakly positive in both time periods.

\section{Fund Managers’ Decisions:}

Each period fund managers decide whether to invest their assets under management in cash or the momentum strategy. The fund managers' skills enable them to observe the state before choosing how to allocate funds between momentum and cash. Managers are risk neutral and maximize their expected management fee taking investors' return-chasing behavior and the

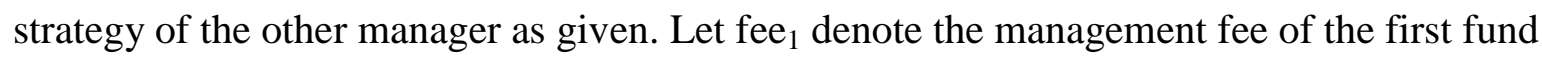
manager. 


\section{Period 2 Strategies:}

There are 16 states of nature at the beginning of period 2. The states are characterized by what each of the two managers choses (to invest in momentum or cash), the realization of the period 1 return on momentum (up or down), and the state going into period 2 (good or bad) i.e., $2^{4}=16$. Without loss of generality, consider the strategies available to manager 1 at the beginning of period 2 in each of the 16 states. If manager 1 did not invest at the beginning of period 1 ( 8 of the 16 states), investing at the beginning of period 2 dominates not investing. To see this, note that when the manager does not invest at the beginning of period 2 , he will get no fees at the end of period 2. Investing gives positive fees with positive probability. So, for 8 of the states the strategy is to invest regardless of what the other manager chooses to do. Suppose manager 1 had invested in momentum at the beginning of period 1 and the return on momentum was down (4 of the remaining 8 states). Given our assumption that $\left(\mathrm{R}_{\mathrm{down}}+\mathrm{f}\right) * \mathrm{R}_{\mathrm{up}}<(1+\mathrm{f})$, the manager will get no fees regardless of his period 2 investment decision. Suppose manager 1 had invested in momentum at the beginning of period 1 and the return on momentum was up (the remaining 4 states). Then manager 1 will have $\mathrm{R}_{\mathrm{up}}+1$ or $\mathrm{R}_{\mathrm{up}}+2$ assets under management depending upon manager 2's investment decision at the beginning of period 1. Suppose the state is bad at the beginning of period 2 . Then manager 1 will always invest if $\left[\left(R_{u p}+1\right) R_{u p}-2\right] * P_{U B}>$ $\left(R_{u p}-1\right)$. We limit our parameter space to values of $R_{u p}$ and $P_{U B}$ such that $\left[\left(R_{u p}+1\right) R_{u p}-2\right] * P_{U B}>$ $\left(\mathrm{R}_{\mathrm{up}}-1\right)$. Since $\mathrm{P}_{\mathrm{UG}}>\mathrm{P}_{\mathrm{UB}}$, manger 1 will always choose to invest regardless of the state at the beginning of period 2. To summarize, manager 1 will always invest in momentum at the beginning of period 2. He will only be paid a fee if the momentum strategy has a high return $R_{u p}$ in period 2. We have therefore shown that at the beginning of period 2, both managers will remain invested in momentum.

Now consider the decision rule of manager 1 at the beginning of period 1 . Given that the optimal strategy during period 2 is to always invest in momentum, the expected management fee conditional on the period 1 state and period 1 investment decision of manager 2 can be written as follows. 


\section{Given: Bad State $\left(\mathrm{st}_{1}=\mathrm{bad}\right)$ in period 1 , Manager 2 holds cash in period 1.}

Expected fee of Manager 1 to investing in momentum in period 1:

$\mathrm{E}\left[\mathrm{fee}_{1} \mid \mathrm{mom}, \mathrm{cash}, \mathrm{st}_{1}=\mathrm{bad}\right]=\left[p_{U B} *\left(\pi_{B, B} * p_{U B}+\pi_{B, G} * p_{U G}\right)\right] *\left[\left(R_{u p}^{2}+2 R_{u p}-3\right) \delta\right]$.

Expected fee of Manager 1 to holding cash in period 1:

$\mathrm{E}\left[\mathrm{fee}_{1} \mid\right.$ cash,cash, $\left.\mathrm{st}_{1}=\mathrm{bad}\right]=\left\{\left[p_{U B} *\left(\pi_{B, B} * p_{U B}+\pi_{B, G} * p_{U G}\right)\right] *\left[\left(2 R_{u p}-2\right) \delta\right]\right\}+$ $\left\{\left[\left(1-p_{U B}\right) *\left(\pi_{B, B} * p_{U B}+\pi_{B, G} * p_{U G}\right)\right] *\left[\left(R_{u p}+f R_{u p}-1-f\right) \delta\right]\right\}$.

(8b)

Given: Bad State $\left(s_{1}=\right.$ bad) in period 1 , Manager 2 invests in momentum in period 1. Expected fee of Manager 1 when investing in momentum in period 1:

$\mathrm{E}\left[\mathrm{fee}_{1} \mid \mathrm{mom}, \mathrm{mom}, \mathrm{st}_{1}=\mathrm{bad}\right]=\left[p_{U B} *\left(\pi_{B, B} * p_{U B}+\pi_{B, G} * p_{U G}\right)\right] *\left[\left(R_{u p}^{2}+R_{u p}-2\right) \delta\right] . \quad(8 \mathrm{c})^{18}$

Expected fee of Manager 1 to holding cash in period 1:

$\mathrm{E}\left[\mathrm{fee}_{1} \mid\right.$ cash $\left., \mathrm{mom}, \mathrm{st}_{1}=\mathrm{bad}\right]=\left\{\left[p_{U B} *\left(\pi_{B, B} * p_{U B}+\pi_{B, G} * p_{U G}\right)\right] *\left[\left(R_{u p}-1\right) \delta\right]\right\}+\left\{\left[\left(1-p_{U B}\right) *\right.\right.$ $\left.\left.\left(\pi_{B, B} * p_{U B}+\pi_{B, G} * p_{U G}\right)\right] *\left[\left(R_{u p}+2 f R_{u p}-1-2 f\right) \delta\right]\right\}$.

\section{Given: Good State $\left(\mathbf{s t}_{1}=\right.$ good) in period 1, Manager 2 holds cash in period 1.}

Expected fee of Manager 1 when investing in momentum in period 1:

$\mathrm{E}\left[\mathrm{fee}_{1} \mid \mathrm{mom}, \mathrm{cash}, \mathrm{st}_{1}=\mathrm{Good}\right]=\left[p_{U G} *\left(\pi_{G, B} * p_{U B}+\pi_{G, G} * p_{U G}\right)\right] *\left[\left(R_{u p}^{2}+2 R_{u p}-3\right) \delta\right]$.

Expected fee of Manager 1 when holding cash in period 1:

$\mathrm{E}\left[\mathrm{fee}_{1} \mid\right.$ cash,cash, $\left.\mathrm{st}_{1}=\mathrm{Good}\right]=\left\{\left[p_{U G} *\left(\pi_{G, B} * p_{U B}+\pi_{G, G} * p_{U G}\right)\right] *\left[\left(2 R_{u p}-2\right) \delta\right]\right\}+$ $\left\{\left[\left(1-p_{U G}\right) *\left(\pi_{G, B} * p_{U B}+\pi_{G, G} * p_{U G}\right)\right] *\left[\left(R_{u p}+f R_{u p}-1-f\right) \delta\right]\right\}$.

\footnotetext{
${ }^{18}$ Note that (8c) implicitly assumes that the case where $R_{\text {down }}$ in period 1 is followed by $R_{\text {up }}$ in period 2 yields zero fees, which is only true if $\left(R_{\text {down }}+f\right) R_{u p}-(1+f)<0$, or equivalently, $R_{\text {down }} R_{u p}<1-f\left(R_{u}-1\right)$.
} 


\section{Given: Good State $\left(\mathrm{st}_{1}=\right.$ good) in period 1, Manager 2 invests in momentum in period 1.}

Expected fee of Manager 1 when investing in momentum in period 1:

$\mathrm{E}\left[\mathrm{fee}_{1} \mid \mathrm{mom}, \mathrm{mom}, \mathrm{st}_{1}=\mathrm{Good}\right]=\left[p_{U G} *\left(\pi_{G, B} * p_{U B}+\pi_{G, G} * p_{U G}\right)\right] *\left[\left(R_{u p}^{2}+R_{u p}-2\right) \delta\right]$.

Expected fee of Manager 1 when holding cash in period 1:

$\mathrm{E}\left[\right.$ fee $_{1} \mid$ cash,mom, $\left.\mathrm{st}_{1}=\mathrm{Good}\right]=\left\{\left[p_{U G} *\left(\pi_{G, B} * p_{U B}+\pi_{G, G} * p_{U G}\right)\right] *\left[\left(R_{u p}-1\right) \delta\right]\right\}+$ $\left\{\left[\left(1-p_{U G}\right) *\left(\pi_{G, B} * p_{U B}+\pi_{G, G} * p_{U G}\right)\right] *\left[\left(R_{u p}+2 f R_{u p}-1-2 f\right) \delta\right]\right\}$.

We are interested in showing that for reasonable parameter values, an equilibrium with the following properties exists: (A) If investors could directly invest in momentum after observing the state, they would prefer to hold cash in the bad state. (B) Despite their ability to observe the state, all fund managers choose to remain invested in momentum when period 1 is a bad state. (C) Investors who use the steady state probabilities implied by the Markov transition probability matrix to compute expected values prefer to allocate funds to managers rather than hold cash even though they know that managers will always remain invested in momentum. In addition, previously discussed parameter restrictions include (D) $p_{U B}>\frac{R_{u p}-1}{\left(1+R_{u p}\right) R_{u p}-2}$ and (E) $R_{\text {down }} R_{u p}<$ $1-f\left(R_{u}-1\right)$

A) Implies $p_{U B} R_{u p}+\left(1-p_{U B}\right) R_{\text {down }}<1$

B) Implies (8a) $>(8 b)$ and (8c) $>(8 d)$, which also automatically ensures (8e) $>(8 f)$ and $(8 \mathrm{~g})>(8 \mathrm{~h})$

C) Implies $p_{G} E\left[m \mid s t_{1}=\right.$ good $]+p_{B} E\left[m \mid s t_{1}=\right.$ bad $]>0$

Where:

$\boldsymbol{P}=\left[p_{G} p_{B}\right]$ is the row vector of steady-state probabilities that satisfy $\boldsymbol{P} \boldsymbol{\Pi}=\boldsymbol{P}$ for the matrix of transition probabilities $\Pi$;

and $m$ is the money returned to an investor at the end of period 2, in excess of what was invested; 


$$
\begin{aligned}
& E\left[m \mid s t_{1}=\text { good }\right]=p U U G *\left[\left(R_{u p}^{2}+R_{u p}-2\right) *(1-\delta)\right]+p U D G *\left[R_{\text {up }} R_{\text {down }}+R_{\text {down }}-\right. \\
& 2]+p D U G *\left[R_{\text {down }} R_{u p}+f R_{\text {up }}-1-f\right]+p D D G *\left[R_{\text {down }} R_{\text {down }}+f R_{\text {down }}-1-f\right] ; \\
& E\left[m \mid s t_{1}=\text { bad }\right]=p U U B *\left[\left(R_{u p}^{2}+R_{u p}-2\right) *(1-\delta)\right]+p U D B *\left[R_{\text {up }} R_{\text {down }}+R_{\text {down }}-\right. \\
& 2]+p D U B *\left[R_{\text {down }} R_{\text {up }}+f R_{\text {up }}-1-f\right]+p D D B *\left[R_{\text {down }} R_{\text {down }}+f R_{\text {down }}-1-f\right] ;
\end{aligned}
$$

where $p U U G=\left[p_{U G} *\left(\pi_{G, B} * p_{U B}+\pi_{G, G} * p_{U G}\right)\right]$ is the probability of drawing two up returns conditional on the good state in period 1, and $p U D G, p D U G, p D D G, p U U B, p U D B, p D U B$, $p D D B$ are similarly defined.

For reasonable parameter values $\left(\mathrm{R}_{\mathrm{up}}=1.02, \mathrm{R}_{\mathrm{down}}=.75, \mathrm{P}_{\mathrm{UG}}=.99, f=.5, \delta=.2\right.$, and $\pi_{1, j}=.5$ for all $i$ and $j$ ), Figure 4 plots manager 1's profits as a function of his period 1 investment choice and the crash probability (1- $\left.\mathrm{p}_{\mathrm{UB}}\right)$ when the first period is a bad state and manager 2 holds cash. The fund manager is indifferent between investing in momentum or holding cash at the breakeven value of $\mathrm{P}_{\mathrm{UB}}$ equal to .426. As long as the probability of a crash in the bad state is less than (1-.426), manager 1 will prefer to respond to manager 2's decision to hold cash in the bad state by investing in momentum. It can be verified that manager 1 will prefer to respond to manager 2's decision to be in momentum in the bad state by investing in momentum under these conditions.

In Table 5, we confirm that all equilibrium conditions exist for a reasonable choice of a $10 \%$ crash probability in the bad state (i.e., $p_{U B}=0.9$ ). When $p_{U G}=0.99$ and $p_{U B}=0.9$, $R_{\text {up }}=1.02, R_{\text {down }}=0.75, \delta=0.2, f=0.5$, and $\pi_{i j}=0.5$ for all $\mathrm{i}$ and $\mathrm{j}, p_{U U B}=0.8505$ and $p_{D U B}=0.0945$. Table 5 summarizes and confirms that all equilibrium conditions are met. 
Table 5:

Equilibrium conditions of the 2-player game

\begin{tabular}{|l|c|l|}
\hline Condition & Expression & Value \\
\hline (A) & $p_{U B} R_{u p}+\left(1-p_{U B}\right) R_{\text {down }}<1$ & $0.993<1$ \\
\hline (B1) (8a) $>$ (8b) & $p_{U U B}\left[\left(R_{u p}^{2}+2 R_{u p}-3\right) \delta\right]>$ & $0.0137>0.0077$ \\
\hline (B2) (8c) $>$ (8d) & $p_{U U B}\left(2 R_{u p}-2\right) \delta+p_{D U B}\left(R_{u p}+f R_{u p}-1-f\right) \delta$ & $0.0103>0.0042$ \\
\hline (C) & $p_{U U B}\left[\left(R_{u p}^{2}+R_{u p}-2\right) \delta\right]>$ & \\
\hline (D) & $p_{G} E\left[\left(R_{u p}-1\right) \delta\right]+p_{D U B}\left[\left(R_{u p}+2 f R_{u p}-1-2 f\right) \delta\right]$ & $0.0045>0$ \\
\hline (E) & $p_{U B}>\frac{R_{u p}-1}{\left(1+R_{u p}\right) R_{u p}-2}$ & $0.90>0.33$ \\
\hline
\end{tabular}

\subsection{Profit Simulations with CRSP-Era Data}

The example above explains in a simple two-period, two-player game setting the apparent paradox that even though large momentum losses are predictable, sophisticated money managers may nonetheless crowd into the momentum strategy at times of elevated risk. The actual dynamics of conditional momentum returns and predictable crashes and investor returnchasing behavior is too complex for a multiplayer, multi-period game. Instead, we use the CRSP data to calibrate a simulation of the profits managers could expect to earn by following momentum timing strategies when the number of time periods and competing funds are large. Our simulations suggest that managers who aggressively remain invested in momentum even when the likelihood of a crash is high outperform managers who attempt to time the momentum strategy. 


\subsubsection{Fees and Assets under Management}

Our simulations model the profits of money managers who are compensated by collecting a monthly management fee equal to $2 / 12$ ths of a percent of assets under management and a quarterly performance fee of $20 \%$ of profits above a high-water mark. These managers compete with each other to manage the investment funds of return-chasing customers who reallocate their investments each month by withdrawing $1 \%$ of assets under management (AUM) from the managers in the bottom quartile of performance over the past year and invest an equal portion of these funds with the managers in the top quartile of performance over the past year. In addition to the monthly reallocation, investors devote new funds or withdraw existing funds from the momentum strategy each month based on the relative performance of the momentum strategy. We assume these new deposits or withdrawals are equal to $20 \%$ of the difference between the return on the momentum strategy and the return on the value-weighted market portfolio over the past year. Therefore, if the momentum strategy outperformed the market by $10 \%$ over the past year, investors would invest new funds equal to $2 \%$ of existing assets under management. Likewise, if the momentum strategy underperformed by $10 \%$, investors would withdraw $2 \%$ of assets under management. We assume new investment is divided equally amongst the funds in the top quartile of performance over the past year and all funds are subject to withdrawals when the momentum strategy underperforms.

These realistic assumptions - that funds have a fee structure of 2-20 with high-water marks, and investors chase returns by depositing more money in top-performing funds when their track record is good and withdrawing funds from underperforming funds and strategiescreate incentives for money managers to stay invested in the momentum strategy even when the probability of a crash is high. The intuition is simple: the very time that crash risk is high is also the time when a high proportion of AUM is likely to be above high-water marks and a large inflow of new assets awaits any manager who outperforms his peers in the immediate future.

\subsubsection{Simulated Returns}

We simulate 25 years of returns to match the conditional returns and bear markettransition probabilities of the CRSP-era Fama-French momentum factor portfolio previously 
reported in Table 4. Specifically, we simulate returns by drawing from an 11-state Markov chain, with states $1-10$ corresponding to the 10 bull market states in Table 4 and state 11 corresponding to the bear markets. We calibrate the Markov transition matrix to match the sample transition probabilities in the CRSP data.

We form a time series of returns via the following algorithm:

1) Begin by selecting a bull market state at random, and draw one monthly momentum and market return pair at random from the sample returns of the selected state.

2) Draw a state at random to transition to, where the probability of transitioning to the next state is determined by the Markov transition matrix calibrated to the CRSP data.

3) If the draw results in another bull state, select a random momentum and market return from the sample returns of the selected state and return to 2) to draw a new state.

4) If the draw is a bear state, select an entire sequence of momentum and market returns from the 63 bear markets in the CRSP data (we choose the entire sequence to assure that once one transitions to a bear market, the momentum strategy will lose at least $5 \%$ ). Once the bear market is complete, draw a new bull state at random from the Markov transition probabilities.

5) Let this process run for 100 years and select the last 25 years for analysis.

6) Repeat steps 1-5 5,000 times to generate 5000 times series of simulated returns.

\subsubsection{Profits as a Function of Risk-Taking}

We wish to show that in our simulations calibrated with CRSP data, money managers who go to cash in periods of elevated crash risk are less profitable on average than managers who remain invested in the momentum strategy. Of course, due to the tournament nature of return-chasing investors, profits depend on the behavior of other fund managers.

We model the behavior of fund managers by assigning each a risk threshold based on the past momentum return percentile beyond which they exit momentum and place their funds in cash earning the risk-free rate. For example, a type 80 manager would invest in the momentum strategy if the past year's momentum return were at or below the $80^{\text {th }}$ percentile of all 1-year lagged returns, while a type 99 manager would not exit momentum until the 1-year lagged return exceeded $99 \%$ of all sample returns. 
The profits of a given type depend on the distribution of types he is competing against. To summarize the riskiness of the distribution of types in a parsimonious manner, we assign a proportion $\alpha$ of managers to the $70-80$ interval at random and a proportion $(1-\alpha)$ of managers to the 90-100 interval at random. Thus, if alpha $=.1,10 \%$ of the managers will be conservative types assigned a uniform random integer between 70 and 80 , and $90 \%$ will be aggressive types assigned a uniform random integer type between 90 and 100 .

We run 5000 simulations of 100 competing fund managers who begin with the same initial assets under management. Table 6 reports the average profits of managers as a proportion of the average profit of the most aggressive, type-100 manager. The more aggressive managers are more profitable on average. For example, in the economy where $90 \%$ of the managers are conservative types $(\alpha=.9)$, the conservative fund managers earn average profits that range from $27.7 \%$ to $68.2 \%$ of the profits of a manager who is always invested. The conservative fund managers underperform by an even worse margin in an economy with more aggressive competitors. In the economy where only $10 \%$ of the managers are conservative types $(\alpha=1)$, the conservative fund managers earn meager average profits that range from $9.64 \%$ to $37.6 \%$ of the profits of a manager who is always invested.

The aggressive type of fund manager earns higher average profits across all values of alpha. These simulations suggest that a profit-maximizing manager who took other managers' behavior, momentum returns, and crash probabilities as given would chose a very high threshold of past return beyond which he would exit momentum and hold cash.

\section{Conclusion}

Using unique historical data on stock returns spanning 140 years, we examine the returns on one of the most popular mechanical trading strategies-momentum. We confirm that momentum investors have enjoyed large abnormal risk-adjusted returns. However, the strategy also incurs infrequent but very large losses.

These losses are more likely to occur during periods when capital is easily available to investors employing the momentum strategy with other people's money. In Victorian London, momentum investors could leverage via margin loans collateralized by the value of their portfolio, and momentum crashes were more likely to occur following large momentum strategy 
gains and periods of easy availability of margin leverage as evidenced by low interest rates. In the CRSP era, when many momentum investors access other people's money through active funds established to invest in momentum, crashes are more likely to occur when the recent performance of momentum has compared well with the overall stock market. These are times when momentum fund managers are likely to find it easy to access the blind capital of returnchasing investors.

In light of the fact that momentum crashes are predictable, why do professional money managers not take steps to avoid momentum crashes? The answer may lie in the fact that the times when the hazard of momentum crashes is high are exactly the times when a momentum fund manager will have a strong recent performance and find it easy to attract funds from returnchasing investors. We show that even sophisticated money managers may rationally crowd into momentum strategies at these times of elevated risk. We argue based on both a stylized model and simulated outcomes from a richer model that a money manager who competes for funds from return-chasing investors and is compensated via fees that are convex in the amount of money managed and the return on that money has an incentive to remain in a crowded momentum trade even when the hazard of large losses is high.

What are the policy implications, if any? There is indeed a growing concern among regulators and market participants that large inflows of capital into trading strategies — such as momentum - may contribute to market fragility. Our findings suggest that regulators who wish to monitor the buildup of crash risk in the financial sector should pay particular attention to strategies that become crowded by inflows of blind capital following recent success. Those are the times when the interests of even sophisticated money managers may start diverging from the interests of those whose money they manage when it comes to deciding how much risk to take. 


\section{References}

Acharya V, Shin H, and T. Yorulmazer, 2010, A theory of slow-moving capital and contagion. Working Paper, New York University.

Agarwal, V., Daniel, N., and Naik, N. Y., 2009, Role of managerial incentives and discretion in hedge fund performance. Journal of Finance 64, 2221-2256.

Aiyagari R, and Gertler M., 1999, Overreaction of asset prices in general equilibrium. Review of Economic Dynamics 2, 3-35.

Allison, P., 1982, Discrete-time methods for the analysis of event histories. Sociological Methodology 13, 61-98.

Ambastha, M., and A. Ben Dor, 2010, Barclays Capital hedge fund replicators in 2009:

Performance review and analysis, Barclays Capital.

Annaert, J. and W. Van Hyfte, 2006, Long-horizon mean reversion for the Brussels Stock Exchange: evidence for the 19th century, Discussion Paper, Ghent University.

Asness, C., T. Moskowitz and L. Pedersen, 2013, Value and momentum everywhere, Journal of Finance 68, 929-985.

Barroso, Pedro, and Pedro Santa-Clara, 2013, Momentum has its moments, Available at SSRN http://papers.ssrn.com/sol3/papers.cfm?abstract_id=2041429.

Ben Dor, A., R. Jagannathan, M. Iwan, and Z. Xu, 2011, What Drives Tracking Errors of Hedge Fund Clones?, Working Paper Northwestern.

Brunnermeier M. and Pedersen L., 2009, Market liquidity and funding liquidity. Review of Financial Studies 22, 2201-2238.

Chiswell, F., 1902, Key to the Rules of the Stock Exchange, London: Effingham Wilson.

Chordia, T. and L. Shivakumar, 2002, Momentum, business cycle, and time-varying expected returns, Journal of Finance 57, 985-1019.

Carpenter, J. N., 2000, Does option compensation increase managerial risk appetite? Journal of Finance 55, 2311-2331

Chabot, B., E. Ghysels and R. Jagannathan, 2009, Momentum cycles and limits to arbitrage: evidence from Victorian England and post-depression US stock markets, NBER Working Paper No. 15591.

Cooper, M. J., R. C. Gutierrez, and A. Hameed, 2004, Market states and momentum, Journal of Finance 59, 1345 - 1365.

Daniel, K., D. Hirshleifer, and A. Subrahmanyam, 1998, Investor psychology and security market under- and overreactions, Journal of Finance 53, 1839 - 1886. 
Daniel K., R. Jagannathan and S. Kim, 2012, Tail Risk in Momentum Strategy Returns, NBER Working Paper, no. 18169

Daniel, K., and T. Moskowitz, 2014, Momentum Crashes, NBER Working Paper, no. 20439

DeLong, J. B., Shleifer, A., Summers, L. H., and Waldmann, R. J., 1990, Positive feedback investment strategies and destabilizing rational speculation, Journal of Finance, 45, 379-395.

Duffie D., Garleanu N, and L. Pedersen, 2002, Securities lending, shorting, and pricing. Journal of Finanial Econonomics 66, 307-39.

Duguid, C., 1902, How to Read the Money Article, London: Effingham Wilson.

Elavia, T., and M. Kim, 2011, Managing the volatility of alpha models, Journal of Investment Management 9, 1-16.

Fama, E., and K. French, 1996, Multifactor explanations of asset pricing anomalies, Journal of Financial Economics 51, 55 - 84.

Fostel A., and J. Geanakoplos, 2008, Leverage cycles and the anxious economy. American Economic Review 98, 1211-1244.

Fung, W., D. Hsieh, N. Naik, and T. Ramadorai, 2008, Hedge funds: Performance, risk, and capital formation. Journal of Finance; 63, 1777-1803.

Geanakoplos John, 2003, Liquidity, default and crashes: endogenous contracts in general equilibrium. In Advances in Economics and Econometrics: Theory and Applications II, Econometric Society Monographs: Eighth World Congress, ed. M Dewatripont, L Hansen, S Turnovsky, 170-205. Cambridge, UK: Cambridge University Press.

Goetzmann, W., 1993, Patterns in Three Centuries of Stock Market Prices, Journal of Business, $66,249-270$.

Goetzmann, W., J. Ingersoll, and S. Ross, 2003, High Water Marks and Hedge Fund Management Contracts, Journal of Finance, 53, 1685-1717.

Goetzmann, W., R.G. Ibbotson, and L. Peng, 2001, A New Historical Database for the NYSE 1815 to 1925: Performance and Predictability, Journal of Financial Markets, 4, 1-32.

Gromb D, Vayanos D, 2002, Equilibrium and Welfare in Markets with Financially Constrained Arbitrageurs, Journal of Financial Economics 66, 361-407

Hong, H., and Stein, J. C., 1999, A unified theory of underreaction, momentum trading, and overreaction in asset markets, Journal of Finance 54, 2143-2184.

Khandani, A., and A. Lo, 2007, What Happened to the Quants in 2007? Journal of Investment Management, 5, 5-54.

Kondor P. 2009. Risk in dynamic arbitrage: price effects of convergence trading. Journal of Finance, 64, 638-658. 
Liu J, and F. Longstaff, 2004, Losing money on arbitrage: optimal dynamic portfolio choice in markets with arbitrage opportunities. Review of Financial Studies 17, 611-641.

Lunde, A. and A. Timmerman, 2004, Analysis of bull and bear markets. Journal of Business and Economic Statistics, 22, 253-273.

Mitchell, M., Pedersen, L. and T. Pulvino, 2007, Slow Moving Capital, American Economic Review, 97, 215-220.

Moskowitz, Tobias, Yao Hua Ooi and Lesse Pedersen, 2012, Time Series Momentum, Journal of Financial Economics 104, 228-250.

Pedersen, L., 2009, When everyone runs for the exit, International Journal of Central Banking, 5, 177-199.

Prentice, R.L., and Gloeckler, L.A., 1978. Regression analysis of grouped survival data with application to the breast cancer data. Biometrics 34, 57-67.

Schwert, G. W., 1989, Why does stock volatility change over time? Journal of Finance 44, 1115 -1153 .

Schwert, G. W., 1990, Stock Returns and real activity, Journal of Finance 45, 1237 - 1257.

Shleifer, A. and Vishny, R.W., 1997, The limits of arbitrage, Journal of Finance, 52, 35 -56.

Swets, J.A., 1988, Measuring the Accuracy of Diagnostic Systems, Science, 240, 1285-1293.

Vayanos, D., and P. Woolley, 2013, An institutional theory of momentum and reversal." Review of Financial Studies 26, 1087-1114. 


\section{Appendices}

\section{The London Stock Market Data: 1866-1907}

The closing bid and ask prices were collected from the quotation list of The Money Market Review, a weekly financial paper published in London between 1860 and 1908. Published on Saturdays, The Money Market Review reprinted H.H. Wetenhall's official quotation list of the previous Friday's closing prices. These were the official prices published by the Committee of the Stock Exchange under the name "Course of the Exchange." The data were sampled every 28 days, rather than the more traditional end-of-month observations, due to the newspaper's weekly publication schedule.

The official list was organized by industry and asset type. The list begins with British government debt, then lists foreign government debt and British, Commonwealth, and foreign railroads, and concludes with commercial securities organized by industry (banks, breweries, canals and docks, insurance, iron, coal and steel, gas, mining, shipping, spinning, waterworks, tea, land, financial and investment trusts, and miscellaneous securities). The Money Market Review's list is not complete. Some industries do not appear on certain dates, and, within industries, individual stocks may have no price for one or more dates. When possible, we filled in the missing price data with The Economist's "Stock Market Prices Current." The Economist's price list included only the largest and most active securities listed in London. Since its coverage was sparse, we only employ the Economist to fill in data that were missing from The Money Market Review. If a section of the official list was omitted from a given Money Market Review, we attempted to replace the missing data with quotes from the Economist.

The data set contains 610,421 bid and ask prices. To minimize entry time and assure quality, the data were double entered by undergraduate research assistants. As a consequence of our data-entry strategy, a stock must appear on the official list for at least one January before it is included in the data set.

The official lists did not differentiate between equity and debt. Today, one would assume that an economist and trained historian would have no problem distinguishing a stock from a bond, but in the $19^{\text {th }}$ century the difference between debt and equity was seldom obvious. The $19^{\text {th }}$ century English publications generally referred to both debt and equity claims as "stocks." A careful examination of the claims each class of shareholder enjoyed usually allowed us to determine if a given security was a debt or equity claim. When selecting which securities to include in our data set, we excluded all securities with fixed interest rates, a face value to be returned at a maturity date, or other obvious characteristics of bonds.

In general, London securities were divided into the following types of asset classes: "stocks," "shares," "ordinary," "common," "limited," "deferred," "preference," "debenture" and "convertible" shares. Whether, the name of the share corresponded to what a modern investor would consider equity depended upon the type of company in question. We looked at each potential security and excluded every security with characteristics similar to modern-day debt. "Common," "limited," and "ordinary" shares were almost always the residual claimants and therefore correspond to modern-day equity. "Stock," on the other hand, was the name given to $19^{\text {th }}$ century bonds! "Preference," "debenture," and "convertible" shares were also excluded, while "deferred" shares generally referred to debt offerings with one notable exception - the investment trusts. Many investment trusts issued only three types of shares: "preference," "debenture," and "deferred." Debenture and preference shares had a fixed dividend rate and often had a maturity date when the nominal amount (face value) of the share would be returned. Deferred shares in investment trusts, on the other hand, were generally the residual claimant to all income in excess of the debenture and preference obligations. We include the deferred shares of investment trusts in our data, provided the trust has no ordinary shares and the deferred shares satisfy our conditions of no maturity date and no cap on dividends. 
For each January, a list of all securities was compiled, meeting our definition of equity. This list of security names and copies of the subsequent year's quotation lists were distributed to research assistants. To eliminate typos, each date was double entered by different research assistants and then compared. Therefore, to appear in the data set, a stock had to appear on the official quotation list for at least one January.

In addition to the closing prices, we collected dividend payments and shares outstanding for each security. These allowed us to compute market values and 28-day holding period returns that accurately reflect dividend payments and stock splits. In total, the data set consists of 610,421 bid and ask prices and 39,090 dividend payments. The dividend payments were collected from the security lists of The Investor's Monthly Manual. ${ }^{19}$ The Investor's Monthly Manual (IMM) published the monthly closing price, shares outstanding, and last four dividends of each security, listed on the London Stock Exchange. We use the IMM to collect dividend and share histories for each security that appears in our data set. Like The Money Market Review, certain securities vanish from the IMM and reappear at a later date without explanation.

\section{Capital Calls and Returns}

We use the price and dividend data to compute the 28-day holding period return for each consecutive price observation. The 28-day holding period gross return is defined as $\left(P_{t+1}+d_{t+1}\right) / P_{t}$, where $P_{t+1}$ and $P_{t}$ are the average of the bid and ask prices at time $t+1$ and $t$, respectively, and $d_{t}$ is the net dividend payments and capital calls (if any) that occurred between time $t$ and $t+1$. Capital calls are a form of reverse dividend common to $19^{\text {th }}$ century stock exchanges.

Many $19^{\text {th }}$ century companies issued shares with a nominal value known as the "amount." The company typically did not require the shareholders to pay for the entire share at the time of issue. Instead, shares were issued with a "par" or "paid" value that was less than the nominal amount of the share. Dividends were based on the par value of the share and not the nominal amount. For example, if a company with a $£ 100$ share with $£ 50$ paid announced a $10 \%$ declared dividend, this would amount to $£ 5$ rather than $£ 10$.

The shareholder was legally obligated to pay the remaining capital (the difference between the nominal and paid amount) at the whim of the company. Thus, the company could "call" upon its shareholders to pay for the remaining value of their shares. This call was apparently binding, as the shares in many bankrupt companies with par values less than nominal amounts traded at negative values when the implicit short put option embedded in the shares was worth more than the company's equity. ${ }^{20}$ To compute holding period returns, we treat capital calls as a negative dividend paid at the beginning of the holding period.

\footnotetext{
${ }^{19}$ The IMM is available online at http://som.yale.edu/imm/html/index.shtml

${ }^{20} \mathrm{We}$ only include stocks with positive values in the analysis that follows.
} 


\section{Figure 1: ROC Curve}

The figure displays the ROC curve from the full hazard model estimated with CRSP-era data to predict bear markets in the Fama-French momentum factor portfolio returns

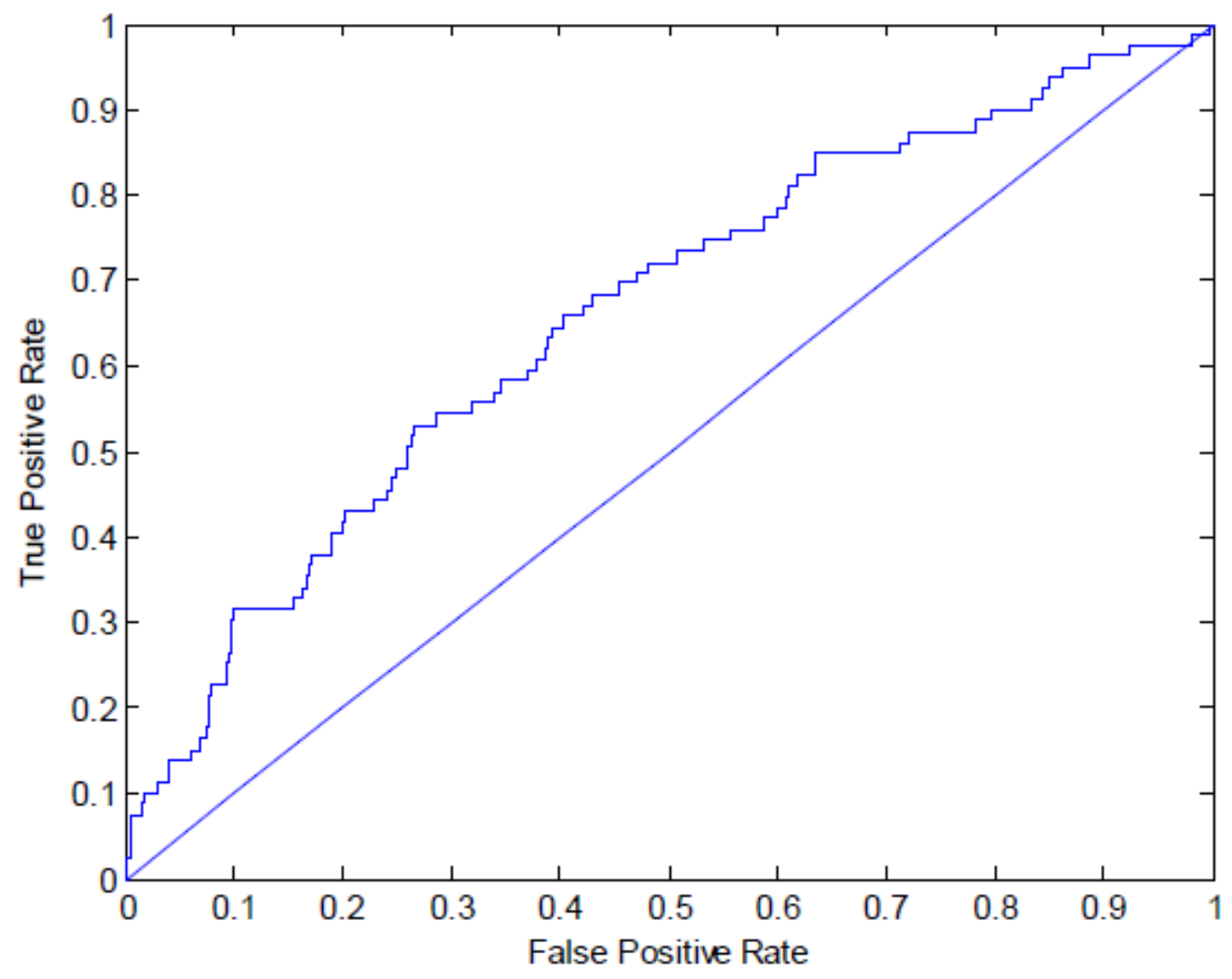




\section{Figure 2:}

\section{Sharp Ratios of CRSP-era Managed Portfolio:}

Plot of the Sharp Ratios of managed portfolios formed by investing in the Fama-French momentum factor portfolio whenever Mpercentile $e_{t}^{K}$ is below a predetermined threshold and investing in the risk-free asset otherwise. Mpercentile $t_{t}^{K}$ is the percentile rank of $R_{t}^{m o m-R m}=R_{(t-12) \rightarrow t}^{m o m}-R_{(t-12) \rightarrow t}^{m}$ in the set of $\left[R_{t-K+1}^{m o m-R m}, \ldots, R_{t}^{m o m-R m}\right]$ and $\mathrm{K}$ is set equal to 36 months.

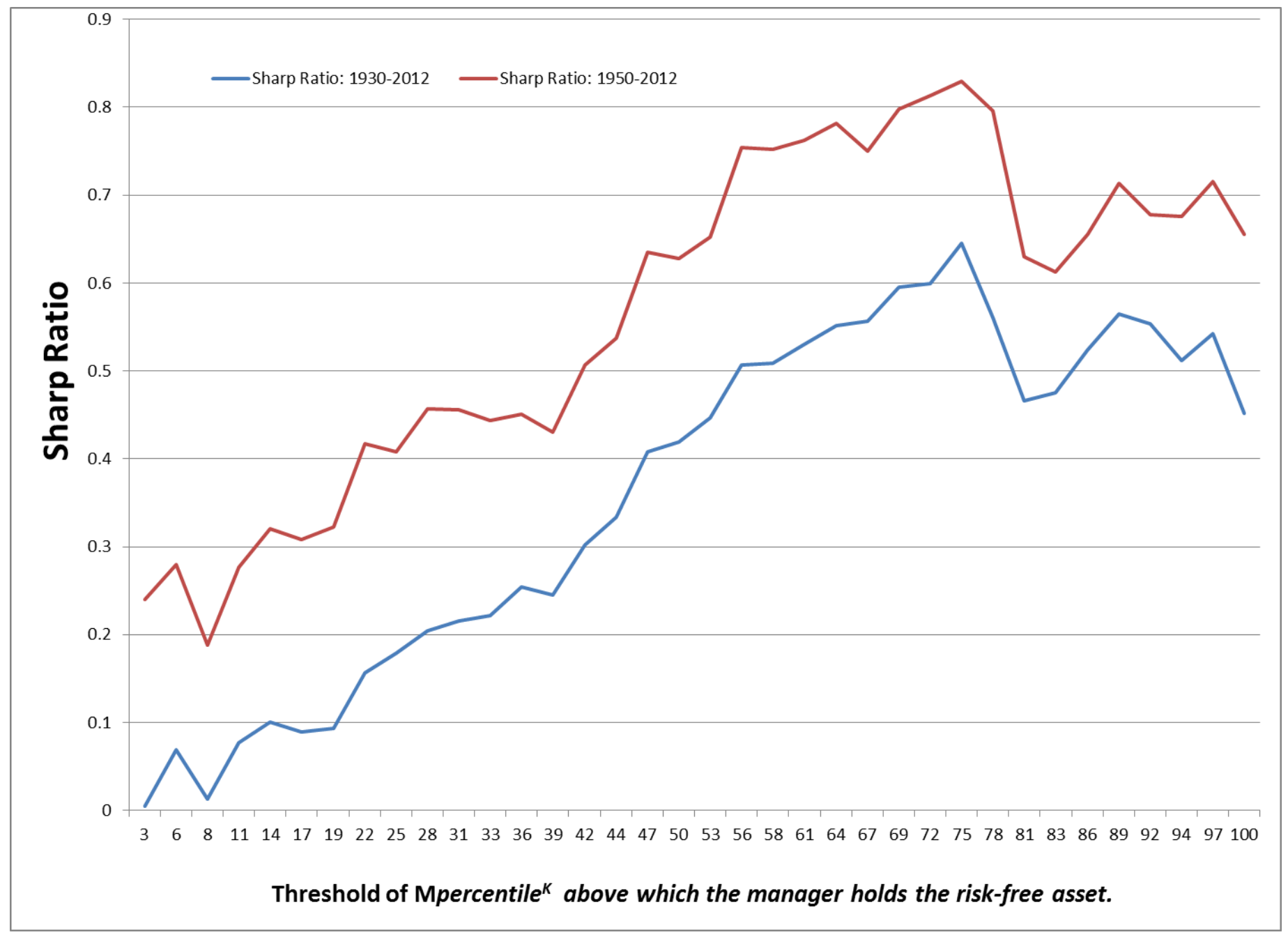




\section{Figure 3: Number of Stocks in London Portfolios}

This study makes use of a new data set of 1,808 stocks (equity) listed in London between 1866 and 1907. The plots display the number of stocks, which decline to 985 in 1903 and 544 in 1904,due to a number of industries vanishing from the quotation list, only to reappear in 1905 .

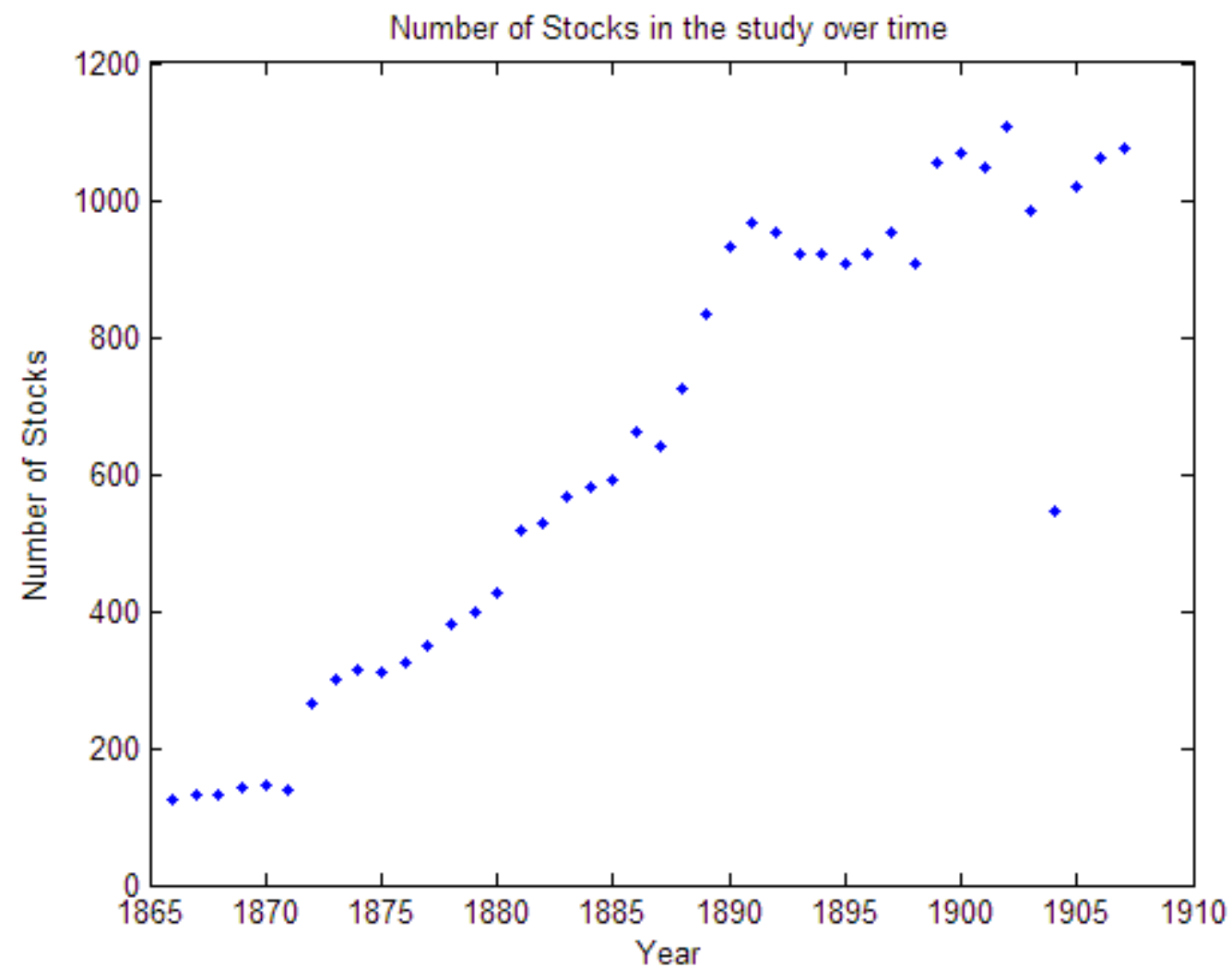




\section{Figure 4: Manager 1's profits as a function of his period 1 investment choice}

Solving the game in section 3.1, the figure plots manager 1's expected profits when the first period is a bad state and manager 2 holds cash, as a function of his period 1 investment choice (hold cash or invest in momentum) and the crash probability (1-p $\mathrm{p}_{\mathrm{UB}}$ ).

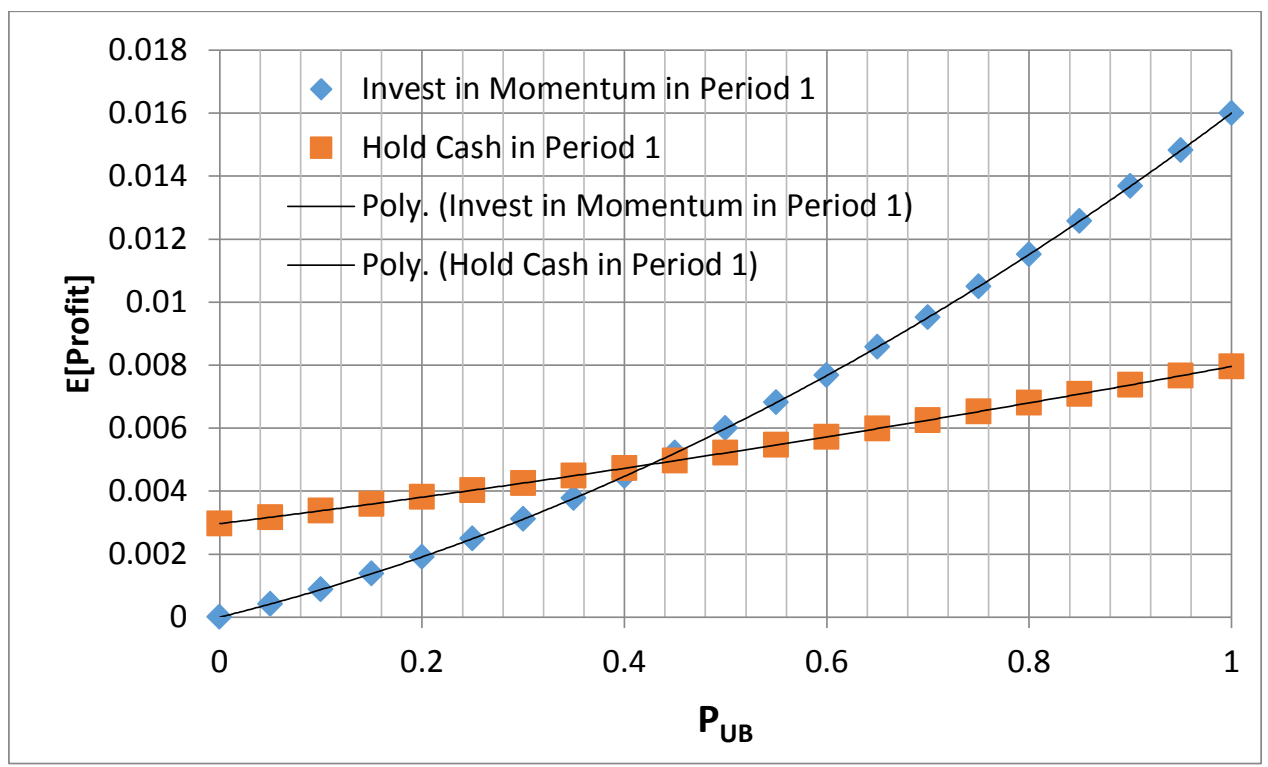


Table 1:

Summary Statistics and Regression Results

\begin{tabular}{|c|c|c|c|c|c|c|}
\hline $\begin{array}{l}\text { Momentum } \\
\text { Portfolio: }\end{array}$ & $\begin{array}{c}\text { CRSP FF } \\
\text { MOM } \\
\text { FACTOR }\end{array}$ & $\begin{array}{c}\text { CRSP FF } \\
\text { MOM } \\
\text { FACTOR }\end{array}$ & $\begin{array}{c}\text { CRSP FF } \\
7030 \text { MOM } \\
\text { PORT }\end{array}$ & $\begin{array}{c}\text { CRSP FF } \\
7030 \text { MOM } \\
\text { PORT }\end{array}$ & $\begin{array}{c}\text { London FF } \\
\text { MOM } \\
\text { FACTOR }\end{array}$ & $\begin{array}{c}\text { London } \\
7030 \text { MOM } \\
\text { PORT }\end{array}$ \\
\hline Sample Dates: & $\begin{array}{l}\text { JUL1927- } \\
\text { DEC2012 } \\
\end{array}$ & $\begin{array}{l}\text { JUL1927- } \\
\text { DEC2012 } \\
\end{array}$ & $\begin{array}{l}\text { JUL1927- } \\
\text { DEC2012 } \\
\end{array}$ & $\begin{array}{l}\text { JUL1927- } \\
\text { DEC2012 }\end{array}$ & $\begin{array}{l}\text { JUL1867- } \\
\text { DEC1907 }\end{array}$ & $\begin{array}{l}\text { JUL1867- } \\
\text { DEC1907 }\end{array}$ \\
\hline \multicolumn{7}{|l|}{ Monthly Returns': } \\
\hline Mean & 0.0069 & & 0.0055 & & 0.003 & 0.0027 \\
\hline St.Dev. & 0.048 & & 0.051 & & 0.0224 & 0.026 \\
\hline Skewness & -3.03 & & -2.89 & & -1.55 & -1.39 \\
\hline Ann. Sharp Ratio: & 0.50 & & 0.37 & & 0.48 & 0.37 \\
\hline \multicolumn{7}{|c|}{ FF- 3 Factor Regression } \\
\hline$\alpha$ & $\begin{array}{l}0.0101 \\
(0.001)^{* * *}\end{array}$ & $\begin{array}{l}0.0101 \\
(0.001)^{* * *}\end{array}$ & $\begin{array}{l}0.0088 \\
(0.001)^{* * *}\end{array}$ & $\begin{array}{l}0.0089 \\
(0.002)^{* * *}\end{array}$ & $\begin{array}{l}0.0052 \\
(.001)^{* * *}\end{array}$ & $\begin{array}{l}0.0049 \\
(.001)^{* * *}\end{array}$ \\
\hline$\beta_{(m k t)}$ & $\begin{array}{l}-0.22 \\
(0.027)^{* * *}\end{array}$ & $\begin{array}{l}-0.34 \\
(0.03)^{* * *}\end{array}$ & $\begin{array}{l}-0.23 \\
(0.029)^{* * *}\end{array}$ & $\begin{array}{l}-0.36 \\
(0.033)^{* * *}\end{array}$ & $\begin{array}{l}-0.45 \\
(0.071)^{* * *}\end{array}$ & $\begin{array}{l}-0.35 \\
(0.079)^{* * *}\end{array}$ \\
\hline$\beta_{\mathrm{SMB}}$ & $\begin{array}{l}-0.07 \\
(0.043)^{*}\end{array}$ & & $\begin{array}{l}-0.10 \\
(0.047)^{* *}\end{array}$ & & & \\
\hline$\beta_{\text {HML }}$ & $\begin{array}{l}-0.45 \\
(0.039)^{* * *}\end{array}$ & & $\begin{array}{l}-0.45 \\
(0.042)^{* * *}\end{array}$ & & & \\
\hline$\beta_{\text {size }}$ & & $\begin{array}{l}-0.31 \\
(0.031)^{* * *}\end{array}$ & & $\begin{array}{l}-0.33 \\
(0.034)^{* * *}\end{array}$ & $\begin{array}{l}-0.10 \\
(0.05)^{* *}\end{array}$ & $\begin{array}{l}-0.32 \\
(0.056)^{* * *}\end{array}$ \\
\hline$\beta_{\text {divyield }}$ & & $\begin{array}{l}-0.31 \\
(0.033)^{* * *}\end{array}$ & & $\begin{array}{l}-0.34 \\
(0.036)^{* * *}\end{array}$ & $\begin{array}{l}-0.11 \\
(0.028)^{* * *}\end{array}$ & $\begin{array}{l}-0.17 \\
(0.031)^{* * *}\end{array}$ \\
\hline$R^{2}$ & 0.22 & 0.22 & 0.21 & 0.22 & .08 & .12 \\
\hline $\mathrm{N}$ & 1026 & 1026 & 1026 & 1026 & 529 & 529 \\
\hline
\end{tabular}

1) CRSP returns are monthly. 1867-1907 returns are 28-day returns. 
Table 2:

Momentum Bear Markets

\begin{tabular}{ccccc} 
& & CRSP FF & London FF & London \\
Momentum & CRSP FF & 7030 & MOM & 7030 \\
Portfolio: & MOM & MOM & FACTOR & MOM \\
& FACTOR & PORT & PORT \\
& & JAN1867- & JAN1867- \\
Sample Dates: & JAN1927- & JAN1927- & DEC1907 & DEC1907 \\
\hline \hline
\end{tabular}

\begin{tabular}{|c|c|c|c|c|}
\hline \multicolumn{5}{|l|}{$\leq-5 \%$ Bear Markets * } \\
\hline \# of bear markets & 63 & 68 & 19 & 21 \\
\hline average duration & 3.7 & 4.9 & 7.3 & 7.9 \\
\hline $\begin{array}{l}\text { average cumlative } \\
\text { decline }\end{array}$ & $13.6 \%$ & $14.8 \%$ & $10.2 \%$ & $11.7 \%$ \\
\hline \multicolumn{5}{|l|}{$\leq-10 \%$ Bear Markets * } \\
\hline \# of bear markets & 30 & 36 & 7 & 9 \\
\hline average duration & 5.6 & 7.4 & 16.7 & 14.7 \\
\hline $\begin{array}{l}\text { average cumlative } \\
\text { decline }\end{array}$ & $20.6 \%$ & $21.6 \%$ & $15.8 \%$ & $16.9 \%$ \\
\hline Monthly observations & 1032 & 1032 & 548 & 548 \\
\hline
\end{tabular}

* Bear markets are dated via the Lunde \& Timmerman (2004) algorithm described in the text $<-5 \%$ bear markets are declines of $5 \%$ or greater and $<-10 \%$ bear markets are declines of $10 \%$ or greater. 
Table 3:

Hazard Model Coefficients

\begin{tabular}{ccccccccc} 
& CRSP FF & CRSP FF & CRSP FF & CRSP FF & CRSP 7030 & CRSP 7030 & CRSP 7030 & CRSP 7030 \\
Momentum Portfolio: & MOM & MOM & MOM & MOM & MOM & MOM & MOM & MOM \\
& FACTOR & FACTOR & FACTOR & FACTOR & PORT & PORT & PORT & PORT \\
Sample Dates: & DEC1927- & APR1930- & DEC1927- & MAR1931- & DEC1927- & MAY1928- & DEC1927- & MAR1931- \\
DEC2012 & DEC2012 & DEC2012 & DEC2012 & DEC2012 & DEC2012 & DEC2012 & DEC2012 \\
$\begin{array}{c}\text { Decline Necessary for } \\
\text { Bear Market }\end{array}$ & $5 \%$ & $5 \%$ & $10 \%$ & $10 \%$ & $5 \%$ & $5 \%$ & $10 \%$ & $10 \%$ \\
\hline \hline
\end{tabular}

\section{Hazard Model}

Coefficients

\begin{tabular}{|c|c|c|c|c|c|c|c|c|}
\hline \multirow[t]{2}{*}{ Constant } & -3.09 & -3.52 & -8.52 & -9.27 & -2.50 & -2.41 & -8.02 & -10.05 \\
\hline & $(1.41)^{* *}$ & $(1.45)^{* *}$ & $(2.15)^{* * *}$ & $(2.42)^{* * *}$ & $(1.09)^{* *}$ & $(1.18)^{* *}$ & $(2.70)^{* * *}$ & $(2.27)^{* * *}$ \\
\hline \multirow[t]{2}{*}{$\rho$} & & 0.94 & & 1.10 & & 0.92 & & 0.85 \\
\hline & & $(0.12)$ & & $(0.17)$ & & $(0.11)$ & & $(0.16)$ \\
\hline \multirow[t]{2}{*}{$\mathrm{Rf}_{\mathrm{t}}$} & -2.48 & -2.69 & 2.63 & 3.28 & -2.65 & -2.69 & 1.76 & -0.13 \\
\hline & $(4.38)$ & $(4.43)$ & $(6.21)$ & $(6.47)$ & $(3.22)$ & $(5.20)$ & $(9.96)$ & $(17.09)$ \\
\hline \multirow[t]{2}{*}{$\operatorname{RETmkt}_{(\mathrm{t}-12)-->(\mathrm{t}-1)}$} & -1.96 & -1.63 & -1.81 & -1.81 & -1.71 & -1.69 & -1.57 & -0.71 \\
\hline & $(0.58)^{* * *}$ & $(0.64)^{* *}$ & $(0.80)^{* *}$ & $(0.92)^{* *}$ & $(0.53)^{* * *}$ & $(0.60) * * *$ & $(1.22)$ & $(0.89)$ \\
\hline \multirow[t]{2}{*}{$\operatorname{RETmom}_{(\mathrm{t}-12)-->(t-1)}$} & 2.50 & 2.70 & 6.06 & 6.4642 & 1.96 & 1.98 & 5.76 & 7.18 \\
\hline & $(0.92)^{* * *}$ & $(0.94)^{* * *}$ & $(1.39)^{* * *}$ & $(1.56)^{* * *}$ & $(0.76)^{* *}$ & $(0.73)^{* * *}$ & $(1.57)^{* * *}$ & $(1.46)^{* * *}$ \\
\hline \multicolumn{9}{|l|}{ Goodness of Fit } \\
\hline LogLiK & -205.75 & -202.19 & -109.93 & -105.99 & -212.29 & -209.37 & -125.21 & -117.98 \\
\hline AUC & $0.68 * * *$ & $0.68 * * *$ & $0.80 * * *$ & $0.80 * * *$ & $0.65 * * *$ & $0.66 * * *$ & $0.76^{* * *}$ & $0.77^{* * *}$ \\
\hline \# of Bear Markets & 63 & 62 & 30 & 29 & 68 & 67 & 36 & 35 \\
\hline $\mathrm{N}$ (times at risk) & 788 & 763 & 852 & 815 & 690 & 686 & 753 & 716 \\
\hline
\end{tabular}


Table 3 cont.

Hazard Model Coefficients

\begin{tabular}{ccccccccc} 
& London FF & London FF & London FF & London FF & London & London & London & London \\
Momentum Portfolio: & MOM & MOM & MOM & MOM & 7030 & 7030 & 7030 & 7030 \\
& FACTOR & FACTOR & FACTOR & FACTOR & MOM & MOM & MOM & MOM \\
Sample Dates: & DEC1867- & DEC1867- & DEC1867- & DEC1867- & DEC1867- & DEC1867- & DEC1867- & DEC1867- \\
DEC1907 & DEC1907 & DEC1907 & DEC1907 & DEC1907 & DEC1907 & DEC1907 & DEC1907 \\
$\begin{array}{c}\text { Decline Necessary for } \\
\text { Bear Market }\end{array}$ & $5 \%$ & $5 \%$ & $10 \%$ & $10 \%$ & $5 \%$ & $5 \%$ & $10 \%$ & $10 \%$ \\
\hline \hline
\end{tabular}

Hazard Model

Coefficients

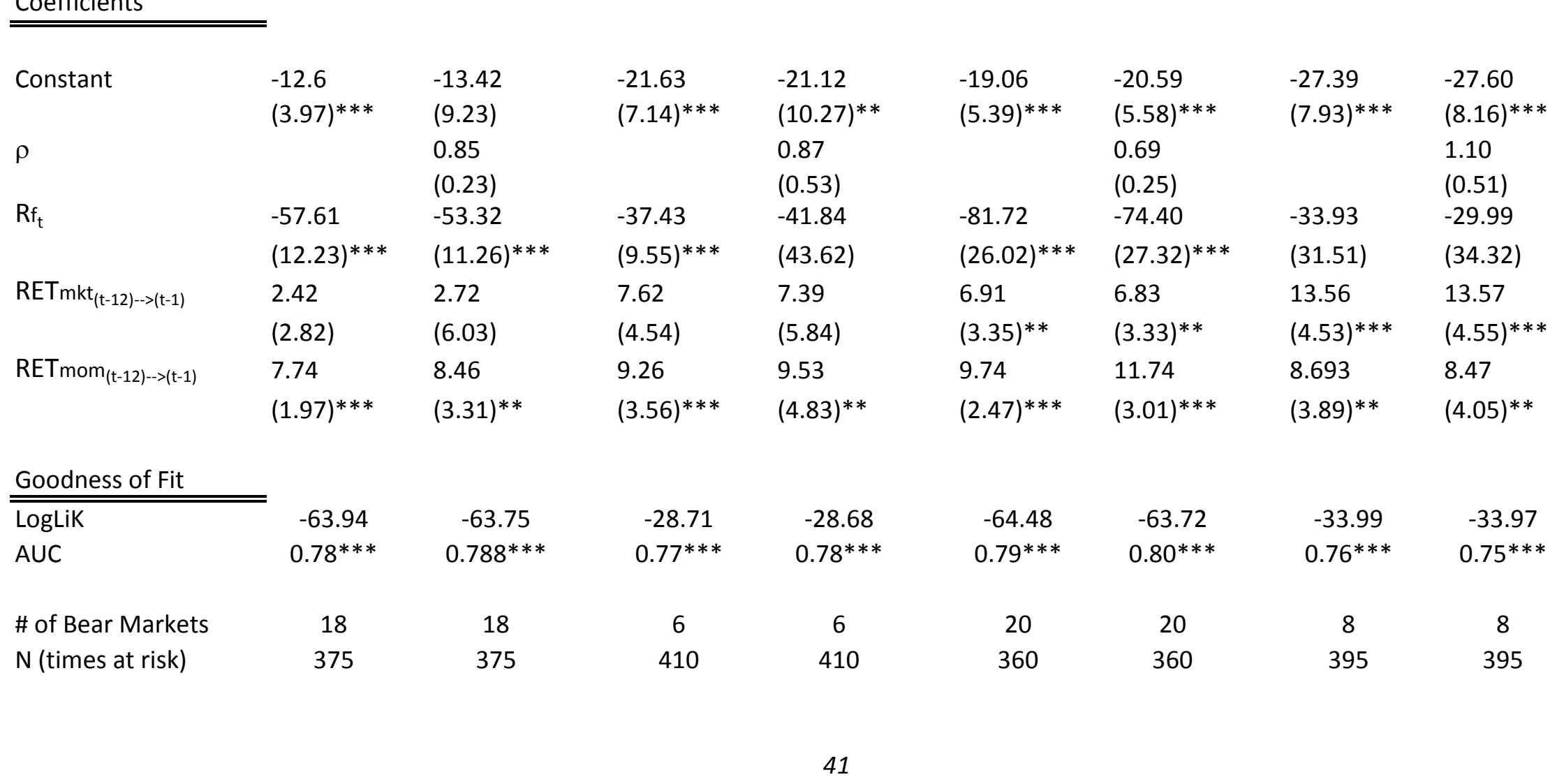


Table 4:

Transition probabilities and conditional returns

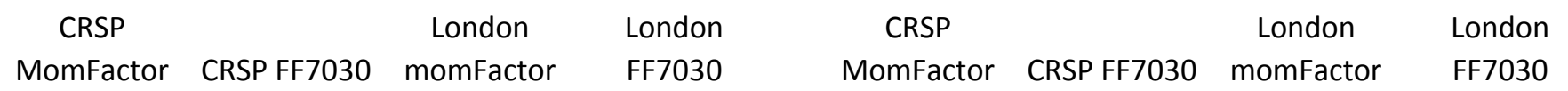

Past 1-year

Return Decile

$\begin{array}{cc}1 & 0.114 \\ 2 & 0.051 \\ 3 & 0.063 \\ 4 & 0.051 \\ 5 & 0.051 \\ 6 & 0.038 \\ 7 & 0.025 \\ 8 & 0.063 \\ 9 & 0.103 \\ 10 & 0.241\end{array}$

Past 1-year

Return Decile

$\begin{array}{cc}1 & 0.017 \\ 2 & 0.022 \\ 3 & 0.014 \\ 4 & 0.014 \\ 5 & 0.015 \\ 6 & 0.016 \\ 7 & 0.016 \\ 8 & 0.014 \\ 9 & 0.023 \\ 10 & 0.039\end{array}$

\begin{tabular}{ccc}
\multicolumn{2}{c}{ Prob of Transition to Bear } & \\
\hline 0.116 & 0.027 & \\
0.087 & 0.000 & 0.000 \\
0.087 & 0.000 & 0.028 \\
0.029 & 0.079 & 0.083 \\
0.059 & 0.054 & 0.028 \\
0.116 & 0.000 & 0.056 \\
0.130 & 0.054 & 0.056 \\
0.044 & 0.105 & 0.114 \\
0.101 & 0.054 & 0.083 \\
0.217 & 0.108 & 0.111
\end{tabular}

\begin{tabular}{r}
$E[R \mid \text { bull }]^{*}$ \\
\hline 0.026 \\
0.020 \\
0.017 \\
0.016 \\
0.021 \\
0.019 \\
0.014 \\
0.021 \\
0.027 \\
0.037
\end{tabular}

$\begin{array}{ll}0.012 & 0.009 \\ 0.003 & 0.009 \\ 0.007 & 0.013 \\ 0.006 & 0.009 \\ 0.007 & 0.011 \\ 0.015 & 0.007 \\ 0.004 & 0.004 \\ 0.012 & 0.009 \\ 0.007 & 0.014 \\ 0.015 & 0.017\end{array}$

\section{Annual Sharp Ratio}

$\begin{array}{llll}0.625 & 1.305 & 2.397 & 2.005 \\ 1.170 & 0.796 & 1.005 & 1.337 \\ 1.602 & 0.617 & 1.613 & 2.704 \\ 1.445 & 1.541 & 0.619 & 1.058 \\ 1.402 & 1.798 & 0.067 & 0.436 \\ 0.748 & 1.129 & 2.945 & 0.940 \\ 1.697 & 0.658 & 0.494 & 0.546 \\ 0.979 & 1.847 & 1.375 & 0.810 \\ 1.416 & 1.606 & 0.901 & 1.452 \\ 0.230 & 0.604 & 1.184 & 1.336\end{array}$

\begin{tabular}{|c|c|c|}
\hline$E[R \mid \text { bear }]^{* *}$ & & \\
\hline-0.064 & -0.007 & NA \\
\hline-0.077 & NA & -0.025 \\
\hline-0.085 & NA & NA \\
\hline-0.053 & -0.021 & -0.028 \\
\hline-0.036 & -0.116 & -0.212 \\
\hline-0.045 & NA & -0.025 \\
\hline-0.041 & -0.021 & -0.018 \\
\hline-0.057 & -0.027 & -0.026 \\
\hline-0.048 & -0.036 & -0.037 \\
\hline-0.079 & -0.040 & -0.040 \\
\hline
\end{tabular}

1. Prob of transitioning to bear = the in-sample frequency of switching from a bull to bear market

* $E[R \mid$ bull $]=$ the in-sample average one month ahead return conditional on remaining in a bull market

** $E[R \mid$ bear $]=$ the in-sample average one month ahead return conditional on switching to a bear market 
Table 6:

Average Profits by Fund Type as a Ratio of Type 100 profits

\begin{tabular}{|c|c|c|c|c|c|}
\hline & $\alpha=.1$ & $\alpha=.25$ & $\alpha=.5$ & $\alpha=.75$ & $\alpha=.9$ \\
\hline \multicolumn{6}{|l|}{ Fund Types* } \\
\hline 70 & 0.1014 & 0.0714 & 0.2753 & 0.1237 & 0.503 \\
\hline 71 & 0.0964 & 0.0655 & 0.2065 & 0.1406 & 0.4223 \\
\hline 72 & 0.323 & 0.015 & 0.2516 & 0.1428 & 0.5439 \\
\hline 73 & 0.0986 & 0.0545 & 0.237 & 0.1547 & 0.5092 \\
\hline 74 & 0.2497 & 0.0504 & 0.2252 & 0.1418 & 0.4921 \\
\hline 75 & 0.3137 & 0.0212 & 0.2281 & 0.1404 & 0.2772 \\
\hline 76 & 0.376 & 0.0147 & 0.2981 & 0.1828 & 0.3574 \\
\hline 77 & 0.1889 & 0.0394 & 0.3339 & 0.1486 & 0.3421 \\
\hline 78 & 0.2507 & 0.0518 & 0.3332 & 0.1636 & 0.4565 \\
\hline 79 & 0.3164 & 0.026 & 0.2806 & 0.177 & 0.4757 \\
\hline 80 & 0.2579 & 0.0347 & 0.3163 & 0.2482 & 0.6824 \\
\hline 90 & 0.339 & 0.066 & 0.448 & 0.5976 & 0.9934 \\
\hline 91 & 0.3158 & 0.0684 & 0.4314 & 0.6936 & 0.7671 \\
\hline 92 & 0.37 & 0.1196 & 0.5096 & 0.9032 & 0.7662 \\
\hline 93 & 0.2717 & 0.0684 & 0.5228 & 1.0395 & 1.1228 \\
\hline 94 & 0.3555 & 0.2626 & 0.6704 & 1.0834 & 1.0729 \\
\hline 95 & 0.3509 & 0.8493 & 0.7123 & 0.8687 & 1.2765 \\
\hline 96 & 0.9373 & 0.3723 & 0.7714 & 0.9315 & 0.7778 \\
\hline 97 & 0.7038 & 0.5704 & 0.9502 & 0.891 & 1.7108 \\
\hline 98 & 0.7999 & 1.0011 & 0.8584 & 0.9504 & 0.8761 \\
\hline 99 & 1.349 & 1.3102 & 1.0362 & 1.0078 & 1.4583 \\
\hline 100 & 1 & 1 & 1 & 1 & 1 \\
\hline
\end{tabular}

* A fund of type $\mathrm{k}$ holds cash if the past-year momentum return exceeds the $\mathrm{k}$-th percentile of all in-sample past year returns and otherwise follows the momentum strategy.

Each cell reports the average profit by fund types in the 5000 simulations as a ratio of type 100 average profits.

each simulation has 100 funds with $\alpha$ proportion of the fund types drawn uniformly from 70-80 interval and (1- $\alpha)$ drawn uniformly from the 90-100 interval 


\section{Working Paper Series}

A series of research studies on regional economic issues relating to the Seventh Federal Reserve District, and on financial and economic topics.

Corporate Average Fuel Economy Standards and the Market for New Vehicles

WP-11-01

Thomas Klier and Joshua Linn

The Role of Securitization in Mortgage Renegotiation

WP-11-02

Sumit Agarwal, Gene Amromin, Itzhak Ben-David, Souphala Chomsisengphet, and Douglas D. Evanoff

Market-Based Loss Mitigation Practices for Troubled Mortgages

Following the Financial Crisis

Sumit Agarwal, Gene Amromin, Itzhak Ben-David, Souphala Chomsisengphet, and Douglas D. Evanoff

Federal Reserve Policies and Financial Market Conditions During the Crisis

WP-11-04

Scott A. Brave and Hesna Genay

The Financial Labor Supply Accelerator

WP-11-05

Jeffrey R. Campbell and Zvi Hercowitz

Survival and long-run dynamics with heterogeneous beliefs under recursive preferences Jaroslav Borovička

WP-11-06

A Leverage-based Model of Speculative Bubbles (Revised)

WP-11-07

Gadi Barlevy

Estimation of Panel Data Regression Models with Two-Sided Censoring or Truncation Sule Alan, Bo E. Honoré, Luojia Hu, and Søren Leth-Petersen

Fertility Transitions Along the Extensive and Intensive Margins

Daniel Aaronson, Fabian Lange, and Bhashkar Mazumder

Black-White Differences in Intergenerational Economic Mobility in the US

WP-11-10

Bhashkar Mazumder

Can Standard Preferences Explain the Prices of Out-of-the-Money S\&P 500 Put Options?

Luca Benzoni, Pierre Collin-Dufresne, and Robert S. Goldstein

WP-11-11

Business Networks, Production Chains, and Productivity:

A Theory of Input-Output Architecture

WP-11-12

Ezra Oberfield

Equilibrium Bank Runs Revisited

WP-11-13

Ed Nosal

Are Covered Bonds a Substitute for Mortgage-Backed Securities?

WP-11-14

Santiago Carbó-Valverde, Richard J. Rosen, and Francisco Rodríguez-Fernández

WP-11-15

The Cost of Banking Panics in an Age before "Too Big to Fail"

Benjamin Chabot 


\section{Working Paper Series (continued)}

Import Protection, Business Cycles, and Exchange Rates:

Evidence from the Great Recession

WP-11-16

Chad P. Bown and Meredith A. Crowley

Examining Macroeconomic Models through the Lens of Asset Pricing

WP-12-01

Jaroslav Borovička and Lars Peter Hansen

The Chicago Fed DSGE Model

WP-12-02

Scott A. Brave, Jeffrey R. Campbell, Jonas D.M. Fisher, and Alejandro Justiniano

Macroeconomic Effects of Federal Reserve Forward Guidance

WP-12-03

Jeffrey R. Campbell, Charles L. Evans, Jonas D.M. Fisher, and Alejandro Justiniano

Modeling Credit Contagion via the Updating of Fragile Beliefs

WP-12-04

Luca Benzoni, Pierre Collin-Dufresne, Robert S. Goldstein, and Jean Helwege

Signaling Effects of Monetary Policy

WP-12-05

Leonardo Melosi

Empirical Research on Sovereign Debt and Default

WP-12-06

Michael Tomz and Mark L. J. Wright

Credit Risk and Disaster Risk

WP-12-07

François Gourio

From the Horse's Mouth: How do Investor Expectations of Risk and Return

Vary with Economic Conditions?

WP-12-08

Gene Amromin and Steven A. Sharpe

Using Vehicle Taxes To Reduce Carbon Dioxide Emissions Rates of

New Passenger Vehicles: Evidence from France, Germany, and Sweden

WP-12-09

Thomas Klier and Joshua Linn

Spending Responses to State Sales Tax Holidays

WP-12-10

Sumit Agarwal and Leslie McGranahan

Micro Data and Macro Technology

WP-12-11

Ezra Oberfield and Devesh Raval

The Effect of Disability Insurance Receipt on Labor Supply: A Dynamic Analysis

WP-12-12

Eric French and Jae Song

Medicaid Insurance in Old Age

WP-12-13

Mariacristina De Nardi, Eric French, and John Bailey Jones

WP-12-14

Fetal Origins and Parental Responses

Douglas Almond and Bhashkar Mazumder 


\section{Working Paper Series (continued)}

Repos, Fire Sales, and Bankruptcy Policy

WP-12-15

Gaetano Antinolfi, Francesca Carapella, Charles Kahn, Antoine Martin,

David Mills, and Ed Nosal

Speculative Runs on Interest Rate Pegs

The Frictionless Case

WP-12-16

Marco Bassetto and Christopher Phelan

Institutions, the Cost of Capital, and Long-Run Economic Growth:

Evidence from the 19th Century Capital Market

WP-12-17

Ron Alquist and Ben Chabot

Emerging Economies, Trade Policy, and Macroeconomic Shocks

WP-12-18

Chad P. Bown and Meredith A. Crowley

The Urban Density Premium across Establishments

WP-13-01

R. Jason Faberman and Matthew Freedman

Why Do Borrowers Make Mortgage Refinancing Mistakes?

WP-13-02

Sumit Agarwal, Richard J. Rosen, and Vincent Yao

Bank Panics, Government Guarantees, and the Long-Run Size of the Financial Sector:

Evidence from Free-Banking America

WP-13-03

Benjamin Chabot and Charles C. Moul

Fiscal Consequences of Paying Interest on Reserves

WP-13-04

Marco Bassetto and Todd Messer

Properties of the Vacancy Statistic in the Discrete Circle Covering Problem

WP-13-05

Gadi Barlevy and H. N. Nagaraja

Credit Crunches and Credit Allocation in a Model of Entrepreneurship

WP-13-06

Marco Bassetto, Marco Cagetti, and Mariacristina De Nardi

Financial Incentives and Educational Investment:

The Impact of Performance-Based Scholarships on Student Time Use

WP-13-07

Lisa Barrow and Cecilia Elena Rouse

The Global Welfare Impact of China: Trade Integration and Technological Change

Julian di Giovanni, Andrei A. Levchenko, and Jing Zhang

WP-13-08

Structural Change in an Open Economy

WP-13-09

Timothy Uy, Kei-Mu Yi, and Jing Zhang

The Global Labor Market Impact of Emerging Giants: a Quantitative Assessment

WP-13-10

Andrei A. Levchenko and Jing Zhang 


\section{Working Paper Series (continued)}

Size-Dependent Regulations, Firm Size Distribution, and Reallocation

WP-13-11

François Gourio and Nicolas Roys

Modeling the Evolution of Expectations and Uncertainty in General Equilibrium

WP-13-12

Francesco Bianchi and Leonardo Melosi

Rushing into American Dream? House Prices, Timing of Homeownership, and Adjustment of Consumer Credit

Sumit Agarwal, Luojia Hu, and Xing Huang

WP-13-13

The Earned Income Tax Credit and Food Consumption Patterns

WP-13-14

Leslie McGranahan and Diane W. Schanzenbach

Agglomeration in the European automobile supplier industry

WP-13-15

Thomas Klier and Dan McMillen

Human Capital and Long-Run Labor Income Risk

WP-13-16

Luca Benzoni and Olena Chyruk

The Effects of the Saving and Banking Glut on the U.S. Economy

WP-13-17

Alejandro Justiniano, Giorgio E. Primiceri, and Andrea Tambalotti

A Portfolio-Balance Approach to the Nominal Term Structure

WP-13-18

Thomas B. King

Gross Migration, Housing and Urban Population Dynamics

WP-13-19

Morris A. Davis, Jonas D.M. Fisher, and Marcelo Veracierto

Very Simple Markov-Perfect Industry Dynamics

WP-13-20

Jaap H. Abbring, Jeffrey R. Campbell, Jan Tilly, and Nan Yang

Bubbles and Leverage: A Simple and Unified Approach

WP-13-21

Robert Barsky and Theodore Bogusz

The scarcity value of Treasury collateral:

Repo market effects of security-specific supply and demand factors

WP-13-22

Stefania D'Amico, Roger Fan, and Yuriy Kitsul

Gambling for Dollars: Strategic Hedge Fund Manager Investment

WP-13-23

Dan Bernhardt and Ed Nosal

Cash-in-the-Market Pricing in a Model with Money and

Over-the-Counter Financial Markets

WP-13-24

Fabrizio Mattesini and Ed Nosal

An Interview with Neil Wallace

WP-13-25

David Altig and Ed Nosal 


\section{Working Paper Series (continued)}

Firm Dynamics and the Minimum Wage: A Putty-Clay Approach

WP-13-26

Daniel Aaronson, Eric French, and Isaac Sorkin

Policy Intervention in Debt Renegotiation:

Evidence from the Home Affordable Modification Program

WP-13-27

Sumit Agarwal, Gene Amromin, Itzhak Ben-David, Souphala Chomsisengphet, Tomasz Piskorski, and Amit Seru

The Effects of the Massachusetts Health Reform on Financial Distress

WP-14-01

Bhashkar Mazumder and Sarah Miller

Can Intangible Capital Explain Cyclical Movements in the Labor Wedge?

WP-14-02

François Gourio and Leena Rudanko

Early Public Banks

William Roberds and François R. Velde

WP-14-03

Mandatory Disclosure and Financial Contagion

WP-14-04

Fernando Alvarez and Gadi Barlevy

The Stock of External Sovereign Debt: Can We Take the Data at 'Face Value'?

WP-14-05

Daniel A. Dias, Christine Richmond, and Mark L. J. Wright

Interpreting the Pari Passu Clause in Sovereign Bond Contracts:

It's All Hebrew (and Aramaic) to Me

WP-14-06

Mark L. J. Wright

AIG in Hindsight

WP-14-07

Robert McDonald and Anna Paulson

WP-14-08

On the Structural Interpretation of the Smets-Wouters "Risk Premium" Shock

Jonas D.M. Fisher

Human Capital Risk, Contract Enforcement, and the Macroeconomy

WP-14-09

Tom Krebs, Moritz Kuhn, and Mark L. J. Wright

Adverse Selection, Risk Sharing and Business Cycles

WP-14-10

Marcelo Veracierto

Core and 'Crust': Consumer Prices and the Term Structure of Interest Rates

WP-14-11

Andrea Ajello, Luca Benzoni, and Olena Chyruk

The Evolution of Comparative Advantage: Measurement and Implications

WP-14-12 Andrei A. Levchenko and Jing Zhang 


\section{Working Paper Series (continued)}

Saving Europe?: The Unpleasant Arithmetic of Fiscal Austerity in Integrated Economies

WP-14-13

Enrique G. Mendoza, Linda L. Tesar, and Jing Zhang

Liquidity Traps and Monetary Policy: Managing a Credit Crunch

WP-14-14

Francisco Buera and Juan Pablo Nicolini

Quantitative Easing in Joseph's Egypt with Keynesian Producers

WP-14-15

Jeffrey R. Campbell

Constrained Discretion and Central Bank Transparency

WP-14-16

Francesco Bianchi and Leonardo Melosi

Escaping the Great Recession

WP-14-17

Francesco Bianchi and Leonardo Melosi

WP-14-18

More on Middlemen: Equilibrium Entry and Efficiency in Intermediated Markets

$(2-18$

Ed Nosal, Yuet-Yee Wong, and Randall Wright

Preventing Bank Runs

WP-14-19

David Andolfatto, Ed Nosal, and Bruno Sultanum

The Impact of Chicago's Small High School Initiative

WP-14-20

Lisa Barrow, Diane Whitmore Schanzenbach, and Amy Claessens

Credit Supply and the Housing Boom

WP-14-21

Alejandro Justiniano, Giorgio E. Primiceri, and Andrea Tambalotti

WP-14-22

The Effect of Vehicle Fuel Economy Standards on Technology Adoption

Thomas Klier and Joshua Linn

What Drives Bank Funding Spreads?

WP-14-23

Thomas B. King and Kurt F. Lewis

Inflation Uncertainty and Disagreement in Bond Risk Premia

WP-14-24

Stefania D'Amico and Athanasios Orphanides

Access to Refinancing and Mortgage Interest Rates:

WP-14-25

HARPing on the Importance of Competition

Gene Amromin and Caitlin Kearns

Private Takings

WP-14-26

Alessandro Marchesiani and Ed Nosal

Momentum Trading, Return Chasing, and Predictable Crashes

WP-14-27

Benjamin Chabot, Eric Ghysels, and Ravi Jagannathan 


\section{Working Paper Series}

A series of research studies on regional economic issues relating to the Seventh Federal Reserve District, and on financial and economic topics.

Corporate Average Fuel Economy Standards and the Market for New Vehicles

WP-11-01

Thomas Klier and Joshua Linn

The Role of Securitization in Mortgage Renegotiation

WP-11-02

Sumit Agarwal, Gene Amromin, Itzhak Ben-David, Souphala Chomsisengphet, and Douglas D. Evanoff

Market-Based Loss Mitigation Practices for Troubled Mortgages

Following the Financial Crisis

Sumit Agarwal, Gene Amromin, Itzhak Ben-David, Souphala Chomsisengphet, and Douglas D. Evanoff

Federal Reserve Policies and Financial Market Conditions During the Crisis

WP-11-04

Scott A. Brave and Hesna Genay

The Financial Labor Supply Accelerator

WP-11-05

Jeffrey R. Campbell and Zvi Hercowitz

Survival and long-run dynamics with heterogeneous beliefs under recursive preferences Jaroslav Borovička

WP-11-06

A Leverage-based Model of Speculative Bubbles (Revised)

WP-11-07

Gadi Barlevy

Estimation of Panel Data Regression Models with Two-Sided Censoring or Truncation Sule Alan, Bo E. Honoré, Luojia Hu, and Søren Leth-Petersen

Fertility Transitions Along the Extensive and Intensive Margins

Daniel Aaronson, Fabian Lange, and Bhashkar Mazumder

Black-White Differences in Intergenerational Economic Mobility in the US

WP-11-10

Bhashkar Mazumder

Can Standard Preferences Explain the Prices of Out-of-the-Money S\&P 500 Put Options?

Luca Benzoni, Pierre Collin-Dufresne, and Robert S. Goldstein

WP-11-11

Business Networks, Production Chains, and Productivity:

A Theory of Input-Output Architecture

WP-11-12

Ezra Oberfield

Equilibrium Bank Runs Revisited

WP-11-13

Ed Nosal

Are Covered Bonds a Substitute for Mortgage-Backed Securities?

WP-11-14

Santiago Carbó-Valverde, Richard J. Rosen, and Francisco Rodríguez-Fernández

WP-11-15

The Cost of Banking Panics in an Age before "Too Big to Fail"

Benjamin Chabot 


\section{Working Paper Series (continued)}

Import Protection, Business Cycles, and Exchange Rates:

Evidence from the Great Recession

WP-11-16

Chad P. Bown and Meredith A. Crowley

Examining Macroeconomic Models through the Lens of Asset Pricing

WP-12-01

Jaroslav Borovička and Lars Peter Hansen

The Chicago Fed DSGE Model

WP-12-02

Scott A. Brave, Jeffrey R. Campbell, Jonas D.M. Fisher, and Alejandro Justiniano

Macroeconomic Effects of Federal Reserve Forward Guidance

WP-12-03

Jeffrey R. Campbell, Charles L. Evans, Jonas D.M. Fisher, and Alejandro Justiniano

Modeling Credit Contagion via the Updating of Fragile Beliefs

WP-12-04

Luca Benzoni, Pierre Collin-Dufresne, Robert S. Goldstein, and Jean Helwege

Signaling Effects of Monetary Policy

WP-12-05

Leonardo Melosi

Empirical Research on Sovereign Debt and Default

WP-12-06

Michael Tomz and Mark L. J. Wright

Credit Risk and Disaster Risk

WP-12-07

François Gourio

From the Horse's Mouth: How do Investor Expectations of Risk and Return

Vary with Economic Conditions?

WP-12-08

Gene Amromin and Steven A. Sharpe

Using Vehicle Taxes To Reduce Carbon Dioxide Emissions Rates of

New Passenger Vehicles: Evidence from France, Germany, and Sweden

WP-12-09

Thomas Klier and Joshua Linn

Spending Responses to State Sales Tax Holidays

WP-12-10

Sumit Agarwal and Leslie McGranahan

Micro Data and Macro Technology

WP-12-11

Ezra Oberfield and Devesh Raval

The Effect of Disability Insurance Receipt on Labor Supply: A Dynamic Analysis

WP-12-12

Eric French and Jae Song

Medicaid Insurance in Old Age

WP-12-13

Mariacristina De Nardi, Eric French, and John Bailey Jones

WP-12-14

Fetal Origins and Parental Responses

Douglas Almond and Bhashkar Mazumder 


\section{Working Paper Series (continued)}

Repos, Fire Sales, and Bankruptcy Policy

WP-12-15

Gaetano Antinolfi, Francesca Carapella, Charles Kahn, Antoine Martin,

David Mills, and Ed Nosal

Speculative Runs on Interest Rate Pegs

The Frictionless Case

WP-12-16

Marco Bassetto and Christopher Phelan

Institutions, the Cost of Capital, and Long-Run Economic Growth:

Evidence from the 19th Century Capital Market

WP-12-17

Ron Alquist and Ben Chabot

Emerging Economies, Trade Policy, and Macroeconomic Shocks

WP-12-18

Chad P. Bown and Meredith A. Crowley

The Urban Density Premium across Establishments

WP-13-01

R. Jason Faberman and Matthew Freedman

Why Do Borrowers Make Mortgage Refinancing Mistakes?

WP-13-02

Sumit Agarwal, Richard J. Rosen, and Vincent Yao

Bank Panics, Government Guarantees, and the Long-Run Size of the Financial Sector:

Evidence from Free-Banking America

WP-13-03

Benjamin Chabot and Charles C. Moul

Fiscal Consequences of Paying Interest on Reserves

WP-13-04

Marco Bassetto and Todd Messer

Properties of the Vacancy Statistic in the Discrete Circle Covering Problem

WP-13-05

Gadi Barlevy and H. N. Nagaraja

Credit Crunches and Credit Allocation in a Model of Entrepreneurship

WP-13-06

Marco Bassetto, Marco Cagetti, and Mariacristina De Nardi

Financial Incentives and Educational Investment:

The Impact of Performance-Based Scholarships on Student Time Use

WP-13-07

Lisa Barrow and Cecilia Elena Rouse

The Global Welfare Impact of China: Trade Integration and Technological Change

Julian di Giovanni, Andrei A. Levchenko, and Jing Zhang

WP-13-08

Structural Change in an Open Economy

WP-13-09

Timothy Uy, Kei-Mu Yi, and Jing Zhang

The Global Labor Market Impact of Emerging Giants: a Quantitative Assessment

WP-13-10

Andrei A. Levchenko and Jing Zhang 


\section{Working Paper Series (continued)}

Size-Dependent Regulations, Firm Size Distribution, and Reallocation

WP-13-11

François Gourio and Nicolas Roys

Modeling the Evolution of Expectations and Uncertainty in General Equilibrium

WP-13-12

Francesco Bianchi and Leonardo Melosi

Rushing into American Dream? House Prices, Timing of Homeownership, and Adjustment of Consumer Credit

Sumit Agarwal, Luojia Hu, and Xing Huang

WP-13-13

The Earned Income Tax Credit and Food Consumption Patterns

WP-13-14

Leslie McGranahan and Diane W. Schanzenbach

Agglomeration in the European automobile supplier industry

WP-13-15

Thomas Klier and Dan McMillen

Human Capital and Long-Run Labor Income Risk

WP-13-16

Luca Benzoni and Olena Chyruk

The Effects of the Saving and Banking Glut on the U.S. Economy

WP-13-17

Alejandro Justiniano, Giorgio E. Primiceri, and Andrea Tambalotti

A Portfolio-Balance Approach to the Nominal Term Structure

WP-13-18

Thomas B. King

Gross Migration, Housing and Urban Population Dynamics

WP-13-19

Morris A. Davis, Jonas D.M. Fisher, and Marcelo Veracierto

Very Simple Markov-Perfect Industry Dynamics

WP-13-20

Jaap H. Abbring, Jeffrey R. Campbell, Jan Tilly, and Nan Yang

Bubbles and Leverage: A Simple and Unified Approach

WP-13-21

Robert Barsky and Theodore Bogusz

The scarcity value of Treasury collateral:

Repo market effects of security-specific supply and demand factors

WP-13-22

Stefania D'Amico, Roger Fan, and Yuriy Kitsul

Gambling for Dollars: Strategic Hedge Fund Manager Investment

WP-13-23

Dan Bernhardt and Ed Nosal

Cash-in-the-Market Pricing in a Model with Money and

Over-the-Counter Financial Markets

WP-13-24

Fabrizio Mattesini and Ed Nosal

An Interview with Neil Wallace

WP-13-25

David Altig and Ed Nosal 


\section{Working Paper Series (continued)}

Firm Dynamics and the Minimum Wage: A Putty-Clay Approach

WP-13-26

Daniel Aaronson, Eric French, and Isaac Sorkin

Policy Intervention in Debt Renegotiation:

Evidence from the Home Affordable Modification Program

WP-13-27

Sumit Agarwal, Gene Amromin, Itzhak Ben-David, Souphala Chomsisengphet, Tomasz Piskorski, and Amit Seru

The Effects of the Massachusetts Health Reform on Financial Distress

WP-14-01

Bhashkar Mazumder and Sarah Miller

Can Intangible Capital Explain Cyclical Movements in the Labor Wedge?

WP-14-02

François Gourio and Leena Rudanko

Early Public Banks

William Roberds and François R. Velde

WP-14-03

Mandatory Disclosure and Financial Contagion

WP-14-04

Fernando Alvarez and Gadi Barlevy

The Stock of External Sovereign Debt: Can We Take the Data at 'Face Value'?

WP-14-05

Daniel A. Dias, Christine Richmond, and Mark L. J. Wright

Interpreting the Pari Passu Clause in Sovereign Bond Contracts:

It's All Hebrew (and Aramaic) to Me

WP-14-06

Mark L. J. Wright

AIG in Hindsight

WP-14-07

Robert McDonald and Anna Paulson

WP-14-08

On the Structural Interpretation of the Smets-Wouters "Risk Premium" Shock

Jonas D.M. Fisher

Human Capital Risk, Contract Enforcement, and the Macroeconomy

WP-14-09

Tom Krebs, Moritz Kuhn, and Mark L. J. Wright

Adverse Selection, Risk Sharing and Business Cycles

WP-14-10

Marcelo Veracierto

Core and 'Crust': Consumer Prices and the Term Structure of Interest Rates

WP-14-11

Andrea Ajello, Luca Benzoni, and Olena Chyruk

The Evolution of Comparative Advantage: Measurement and Implications

WP-14-12 Andrei A. Levchenko and Jing Zhang 


\section{Working Paper Series (continued)}

Saving Europe?: The Unpleasant Arithmetic of Fiscal Austerity in Integrated Economies

WP-14-13

Enrique G. Mendoza, Linda L. Tesar, and Jing Zhang

Liquidity Traps and Monetary Policy: Managing a Credit Crunch

WP-14-14

Francisco Buera and Juan Pablo Nicolini

Quantitative Easing in Joseph's Egypt with Keynesian Producers

WP-14-15

Jeffrey R. Campbell

Constrained Discretion and Central Bank Transparency

WP-14-16

Francesco Bianchi and Leonardo Melosi

Escaping the Great Recession

WP-14-17

Francesco Bianchi and Leonardo Melosi

WP-14-18

More on Middlemen: Equilibrium Entry and Efficiency in Intermediated Markets

$(2-18$

Ed Nosal, Yuet-Yee Wong, and Randall Wright

Preventing Bank Runs

WP-14-19

David Andolfatto, Ed Nosal, and Bruno Sultanum

The Impact of Chicago's Small High School Initiative

WP-14-20

Lisa Barrow, Diane Whitmore Schanzenbach, and Amy Claessens

Credit Supply and the Housing Boom

WP-14-21

Alejandro Justiniano, Giorgio E. Primiceri, and Andrea Tambalotti

WP-14-22

The Effect of Vehicle Fuel Economy Standards on Technology Adoption

Thomas Klier and Joshua Linn

What Drives Bank Funding Spreads?

WP-14-23

Thomas B. King and Kurt F. Lewis

Inflation Uncertainty and Disagreement in Bond Risk Premia

WP-14-24

Stefania D'Amico and Athanasios Orphanides

Access to Refinancing and Mortgage Interest Rates:

WP-14-25

HARPing on the Importance of Competition

Gene Amromin and Caitlin Kearns

Private Takings

WP-14-26

Alessandro Marchesiani and Ed Nosal

Momentum Trading, Return Chasing, and Predictable Crashes

WP-14-27

Benjamin Chabot, Eric Ghysels, and Ravi Jagannathan 